2

\title{
3 Using fault displacement and slip tendency to estimate stress
}

$4 \quad$ states.

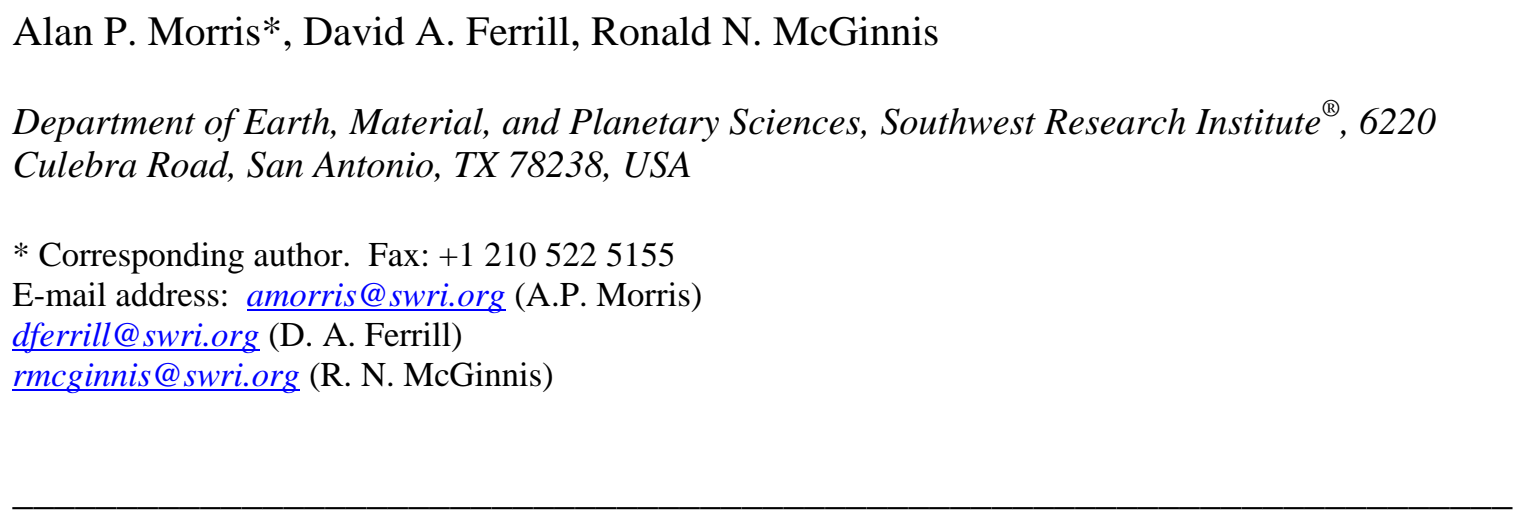


18 We suggest that faults in high slip tendency orientations tend to develop larger

19 displacements than other faults. Consequently, faults that accumulate larger

20 displacements are more likely to be reliable indicators of the longer term stress field and

21 should be weighted accordingly in paleostress estimation. Application of a stress

22 inversion technique that uses slip tendency analyses and fault displacements to interpret

23 populations of coherent normal faults within the Balcones Fault System of south-central

24 Texas provides stress estimates that are consistent with established regional stress

25 analyses. Although the method does not require measurement of slip directions, these

26 data, where available, and sensitivity analyses of the angular mismatch between

27 measured slip directions and those predicted by inverted stress states provide high

28 confidence in the stress estimates generated using slip tendency analyses. Close

29 inspection of the fault orientation and displacement data further indicates that

30 subpopulations of faults with orientations different from the regional pattern have formed

31 in response to stress perturbations generated by displacement gradients on an adjacent

32 seismic scale fault.

33

34 Keywords: Slip tendency, normal, fault, displacement, stress

35

36

37 


\section{Introduction}

Slip tendency $\left(T_{\mathrm{s}}\right)$ is the dimensionless ratio of maximum resolved shear stress to normal stress $(\tau / \sigma)$ acting on a surface and is therefore a function of the orientation of the surface of interest and the form of the stress tensor (Morris et al., 1996). Slip tendency analysis provides useful insights into the distribution of past slip on faults and fractures and the ability to predict behavior of these structures (Morris et al., 1996; Lisle and Srivastava, 2004; Streit and Hillis, 2004; Collettini and Trippetta, 2007). Analysis of slip tendency is predicated on:

(1) Calculation of the state of normal and shear stress for a fault or fracture of any orientation within a stress tensor (e.g., Ramsay, 1967; Ramsay and Lisle, 2000).

(2) The assumption that the resolved shear and normal stresses on a surface are strong predictors of both the likelihood and direction of slip (assumed to be equivalent to the direction of the maximum resolved shear stress) on that surface (Wallace, 1951; Bott, 1959; Lisle and Srivastava, 2004).

Although slip tendency is not a direct measure of slip on surfaces, it represents the potential for slip in an applied stress state. Patterns of slip tendency are sensitive to the stress ratio $\left(\Phi=\frac{\left(\sigma_{2}-\sigma_{3}\right)}{\left(\sigma_{1}-\sigma_{3}\right)}\right.$; Angelier, 1975; Morris et al., 1996; Morris and Ferrill, 2009), and a technique exists that uses this property to invert stress states using slip tendency analyses without reference to slip directions (McFarland et al., 2012).

In this paper we explore the relationships among (i) fault orientations, (ii) fault displacements, and (iii) computed slip tendencies for populations of small-displacement faults in mechanically layered limestone to understand the interrelationships between these three parameters. Results of the analysis support the premise that faults that are well oriented for slip in a given stress field tend to develop larger displacements. Consequently, displacement can be considered a key parameter for fault-based stress inversion and should be weighted heavily when inferring paleo-stress conditions from fault populations. 


\section{Background on study area}

The Balcones Fault System is a network of normal faults (Fig. 1) that forms the southern and eastern edge of the Edwards Plateau in central Texas (Cope, 1880; Hill, 1889, 1890; Foley, 1926; Weeks, 1945). The fault system cuts Cretaceous strata at the surface and is curved, generally following the subsurface trend of the Late Paleozoic Ouachita Orogen that the Cretaceous strata unconformably overlie (Murray, 1956, 1961; Flawn et al., 1961; Young, 1972). Although the overall Balcones Fault System makes a major bend through central Texas, faults within the system have a narrow range of strikes and are compatible with having formed in a relatively uniform normal faulting stress regime, controlled by vertical maximum principal compressive stress and horizontal minimum principal compressive stress in the direction $150^{\circ}$ (Ferrill et al., 2004; Ferrill et al., 2012). The Hidden Valley Fault is a typical example of a normal fault within the Balcones Fault System (Ferrill et al., 2011; Fig. 1). It has a mapped trace length of approximately 45 $\mathrm{km}$, with a strike of $044^{\circ}$ to $065^{\circ}$, a dip of $60^{\circ}$ to $80^{\circ}$, and a maximum normal, down to the southeast displacement of approximately $60 \mathrm{~m}$. Because of the generally poor exposure in the Texas Hill Country, this trace length may not be a single, continuous, fully linked fault and may include segments linked by relay ramps. Where exposed, the fault displaces rocks of the Lower Cretaceous carbonate section (George, 1952; Abbott, 1966; Ferrill et al., 2004, 2011; Ferrill and Morris, 2008), and likely loses displacement with depth (Ferrill et al., 2011) possibly tipping before penetrating rocks of the Late Paleozoic Ouachita Orogen.

Figure 1 about here

A unique exposure of part of the Hidden Valley Fault Zone was formed in July 2002 when flood waters eroded a gorge into the Glen Rose Formation through the emergency spillway of Canyon Lake (Ward and Ward, 2007; Ferrill et al., 2008, 2011; Ferrill and Morris, 2008; Lamb and Fonstad, 2010). In addition to the fault zone itself, several subhorizontal bedding-parallel pavements were exposed by erosion, and these pavements are cut by networks of small-displacement $(<1 \mathrm{~m}$ ) normal faults (Fig. 2; Ferrill et al., 
The surfaces of these faults are clearly visible and are commonly decorated with slickenlines (slip direction indicators) in the form of grooves, striations, ridges and swales, or fibrous calcite. Detailed stratigraphic mapping (Ferrill et al., 2011) and close inspection of faulted strata permit precise measurements of displacement parallel to slickenlines on every exposed fault surface within Canyon Lake Gorge. Fault measurements (strike, dip, and rake using the right-hand rule, and displacement measured along the fault plane and parallel to the slip indicators) were made at 609 locations on four bedding pavements - three pavements (stratigraphic heights $=19.7,22.8$, and 23.5 $\mathrm{m}$ ) in the footwall (329 locations) and one pavement (stratigraphic height $=86.6 \mathrm{~m}$ ) in the hanging wall (280 locations) of the Hidden Valley fault; pavement names are taken from the stratigraphic numbering scheme outlined in Ward and Ward (2007) and Ferrill et al. (2011). Measurement locations were surveyed and recorded using a real-time kinematic global positioning system (Fig. 3A).

\section{Fieldwork}

\subsection{Hidden Valley Fault}

For a distance of approximately $160 \mathrm{~m}$, the Hidden Valley fault separates the footwall and hanging wall bedding pavements from which detailed fault measurements were made in this study (pavements 19.7, 22.8 and 23.5, and 86.6; see supplemental data). At the Waterfall location (west-southwest end of traverse), total normal throw is $59.2 \mathrm{~m}$ with $4.02 \mathrm{~m}$ accommodated by bed tilting (synthetic dip), $4.28 \mathrm{~m}$ accommodated by synthetic faulting, and the balance $(50.90 \mathrm{~m})$ being carried on a narrow ( $<0.05 \mathrm{~m}$ thick) fault core (Ferrill et al., 2011). The Hidden Valley fault strike is $060^{\circ}$ and the dip is $65^{\circ}$ (to the south-southeast) measured from the fault core. Mapped locations from the footwall and 
hanging wall pavements were projected onto a vertical plane striking $060^{\circ}$ along vectors perpendicular to the projection plane. Drawing form lines through the data clouds produces a representation of the angular geometry (especially along the strike dip component) of the footwall and hanging wall cutoffs against the main plane of the Hidden Valley fault (Fig. 3B). At the northeastern extremity of the area studied in detail, the Hidden Valley fault consists of two segments that bound a breached relay structure (Fig. 3A). The northern bounding fault of the breached relay ramp has a throw of 21.20 $\mathrm{m}$ and the southern bounding fault has a throw of $\sim 28.40 \mathrm{~m}$. Toward the relay ramp, the footwall has an along-fault-strike (towards $060^{\circ}$ ) component of dip of approximately $7^{\circ}$ (Fig. 3B). The hanging wall pavement has a fault-oblique, south-eastward to eastnortheast component of dip of approximately $5^{\circ}$.

\subsection{Footwall pavements}

Sixty-three normal faults were identified and traced on the gently to moderately $\left(2-20^{\circ}\right)$ south-southeasterly dipping surfaces from pavement 19.7 (a $0.1 \mathrm{~m}$ thick dolomitic grainstone), pavement 21.8 (a $0.2 \mathrm{~m}$ thick miliolid-rich calcareous grain-dominated packstone), pavement 22.8 (a $0.3 \mathrm{~m}$ thick vuggy calcareous grain-dominated packstone), and pavement 23.5 (a $1.0 \mathrm{~m}$ thick miliolid-rich calcareous grain-dominated packstone). Fault interactions (relay ramps and branch lines) indicate that the faults form a coherent network across the exposed bedding surface, and fault orientations generally fall into two categories (Figs. 4A and C), those that dip to the north-northwest and those that dip to the south-southeast (Fig. 4A). Slickenline rakes were measured at 328 locations scattered among the exposed fault surfaces from the strike direction clockwise to the slickenline within the slip surface. Rakes vary from $11^{\circ}$ to $150^{\circ}$ with more than $50 \%$ between $80^{\circ}$ and $100^{\circ}$ (i.e., within $\pm 10^{\circ}$ of pure dip slip; Fig. 4B). All slip surfaces exhibit bedextending displacement (i.e., they are normal or oblique-normal faults). Displacements were measured parallel to slickenlines wherever possible, and range from $0.001 \mathrm{~m}$ to 0.91 $\mathrm{m}$, and $90 \%$ of the measured displacements are less than $0.20 \mathrm{~m}$. All measured slip surfaces with displacements greater than $0.20 \mathrm{~m}$ have rakes between $72^{\circ}$ and $112^{\circ}($ Fig. 4B). 


\subsection{Hanging wall pavement}

Two-hundred and eighty measurements of strike, dip, rake of slickenlines, and displacement were made on 104 normal faults that are exposed on the gently $\left(<8^{\circ}\right)$ south-southeasterly dipping surface of pavement 86.6 (a $0.6 \mathrm{~m}$ thick cross-bedded

\subsection{Fault orientation and displacement}

Faults in both the hanging wall and footwall of the Hidden Valley fault at this location exhibit a strong preferred orientation with strikes nearly parallel to strike of the main Hidden Valley Fault, as illustrated by the length-weighted rose diagrams in Fig. 3A. This characteristic is less obvious in stereographic projection plots, but becomes clearer when surfaces with progressively larger displacements are considered (Figs. 4A and D), although there are two faults that do not conform to this pattern in the hanging wall (see Figs. 3A, 4D, and 4F). Most slipped surfaces on both the footwall and hanging wall 
pavements have displacements less than $0.20 \mathrm{~m}$ (Figs. 4B and D). Fault surfaces with larger displacements are less numerous than those with smaller displacements and display a smaller range of orientations (Figs. 4B, C, E, and F). Surfaces with displacements greater than $0.20 \mathrm{~m}$ show a strong bimodal distribution in the footwall pavements with a dominance of south-southeast-dipping faults and a clear maximum, almost coincidental with the orientation of the main Hidden Valley fault at this location (Fig. 4A). The hanging wall fault population has a similar bimodal distribution, but with a preponderance of north-northwest-dipping faults. The two populations are well described in general terms as conjugate normal faults developed in conjunction with the major Hidden Valley fault (Ferrill et al., 2009, 2011).

\subsection{Fault orientations oblique to the main Hidden Valley Fault}

Faults with strikes at a variety of angles to the main Hidden Valley fault are present in both the footwall and hanging wall pavements (Fig. 3A). With two exceptions in the hanging wall, faults with strikes different from the predominant directions $\left(060^{\circ}\right.$ and $240^{\circ}$ in the footwall and $215^{\circ}$ in the hanging wall; see rose diagrams in Fig. 3A) tend to have displacements less than $0.20 \mathrm{~m}$ (Figs. $4 \mathrm{C}$ and F). In the footwall pavements there is a subpopulation of faults with displacements of less than $0.20 \mathrm{~m}$ and strikes from $350^{\circ}$ to $020^{\circ}$ that accommodates bed extension approximately parallel to the strike of the Hidden Valley fault (Figs. 4A and C). In contrast, the hanging wall contains a subpopulation of fault surfaces that strikes approximately $285^{\circ}$ and includes surfaces with displacements of greater than $0.20 \mathrm{~m}$ and as high as $0.63 \mathrm{~m}$ (Figs. 4D and F). This group of faults accommodates extension oblique to the Hidden Valley Fault strike along an azimuth of about $040^{\circ}$ to $045^{\circ}$.

\section{Interpretation of stress state}

\subsection{Introduction and stress magnitudes}

All faults in the mapped area are normal or normal-oblique in displacement. Therefore, 
following Anderson (1951), the maximum principal compressive stress $\left(\sigma_{1}\right)$ was likely vertical or near vertical during faulting, the intermediate principal compressive stress $\left(\sigma_{2}\right)$ was near horizontal and parallel to the strike of the active faults, and the minimum principal compressive stress $\left(\sigma_{3}\right)$ would have been perpendicular to these two. The vertical stress $\left(\sigma_{1}\right)$ would have been the result of the gravitational loading of overlying rock at the time of faulting.

Ferrill et al. (2004) estimated stress conditions within Edwards Group strata during the formation of the Balcones Fault System as a normal-faulting stress regime with $1 \mathrm{~km}$ of water-saturated overburden and an average rock density of $2,700 \mathrm{~kg} / \mathrm{m}^{3}$ with the following effective principal stresses: $\sigma_{1}{ }^{\prime}=17 \mathrm{MPa}$, vertical; $\sigma_{2}{ }^{\prime}=11 \mathrm{MPa}$, horizontal with an azimuth of $055^{\circ}$; and $\sigma_{3}{ }^{\prime}=5 \mathrm{MPa}$, horizontal with an azimuth of $145^{\circ}$. This estimate is based on the assumed stratigraphic thickness of overlying rock at the time of initiation of faulting during the Oligocene, the mapped orientations of faults within the Balcones Fault Zone (Foley, 1926; Murray, 1961; Young, 1972; Maclay and Small, 1983; Collins, 2000), and an assumed uniaxial compressive strength of $50 \mathrm{MPa}$ and coefficient of internal friction of 0.65 for the predominant Trinity Group limestones in the region. The main Hidden Valley fault has an orientation and displacement consistent with this stress state, although its geographic location is to the platform side (northwest) of the Balcones Fault Zone. It is possible that, because the Glen Rose Formation is stratigraphically below the Edwards Group (e.g., Ferrill et al., 2004), the vertical stress may have been greater than $17 \mathrm{MPa}$. However, the extra overburden thickness may have been mitigated by attenuated stratigraphic thicknesses and/or erosion in the platformward location of the Hidden Valley fault. We regard the stress state of Ferrill et al. (2004) as a reasonable starting estimate for the regional stress field responsible for the formation of the Balcones Fault Zone and the Hidden Valley fault and its associated structures, although we prefer a somewhat higher overburden stress (23.8 MPa) because of the deeper stratigraphic position of the Glen Rose Formation. The higher differential stress estimate of Ferrill et al. (2012) is based on calcite twin analysis and possibly results from a local stress anomaly within the Hidden Valley fault zone. 
Based on published stratigraphic thicknesses for post Glen Rose Cretaceous rocks and Tertiary rocks older than the 16 to 20 Ma age estimated for the faulting (Foley, 1926; Murray, 1961; Young, 1972; Maclay and Small, 1983; Collins, 2000), the likely depth of burial of the mapped pavements at the time of faulting was between 1.2 and $2.7 \mathrm{~km}$. This depth range is based on stratigraphic, vitrinite reflectance, and maximum differential stress constraints (Ferrill et al., 2012). Assuming an average density of $2,650 \mathrm{~kg} / \mathrm{m}^{3}$ for the overlying rock sequence suggests a range for vertical stress resulting from overburden of 31 to $70 \mathrm{MPa}$. Deformation behavior of rocks at depth is determined by effective stress, which is defined as the rock stress minus the pore fluid pressure (Terzaghi, 1936). In this example, the simplest estimate of pore pressure assumes that the rock mass at the time of faulting contained continuously connected pore spaces to the near surface and the pore space was occupied by water. Thus, the pore fluid pressure $\left(\sigma_{\mathrm{p}}\right)$ range would have been approximately $12 \mathrm{MPa}$ to $27 \mathrm{MPa}$, and the corresponding range of vertical effective stress $\left(\sigma_{\mathrm{v}}{ }^{\prime}=\sigma_{1}{ }^{\prime}=\sigma_{1}-\sigma_{\mathrm{p}}\right)$ would have been $19 \mathrm{MPa}$ to $43 \mathrm{MPa}$. The presence of faults indicates that the differential effective stress $\left(\sigma_{1}{ }^{\prime}-\sigma_{3}{ }^{\prime}\right.$, where $\left.\sigma_{3}{ }^{\prime}=\sigma_{3}-\sigma_{\mathrm{p}}\right)$ was sufficient to initiate and accumulate slip on fractures, and thus must have exceeded both the cohesive strength and the internal friction of the rock (e.g., Collettini and Sibson, 2001). A reasonable range of rock internal friction is 0.4 to 0.85 with a value of 0.6 often cited as typical (Byerlee, 1978). The coefficient of internal friction for rock is mathematically equivalent to the threshold slip tendency at which a fault or fracture will slip (Morris et al., 1996).

\subsection{Stress orientations}

A first-pass estimate of stress orientations can be made using the strong preferred orientation of normal fault slip surfaces accommodating most of the measured displacement in the footwall and hanging wall pavements (Fig. 3) and the close accordance between this and the strike of the Hidden Valley Fault. These observations lead to a consistent interpretation of a $\sigma_{2}$ orientation that is subhorizontal with an azimuth of $055^{\circ}$ to $060^{\circ}$, and this agrees with Ferrill et al. (2004). The orientation of $\sigma_{3}$ would be near horizontal with an azimuth of $145^{\circ}$ to $150^{\circ}$ (147 in Ferrill et al., 2012). 


\section{Use of faults to estimate paleostress}

\subsection{Introduction and discussion of slip tendency and stress inversion}

It is commonly assumed that the orientation of the maximum resolved shear stress on a surface is a proxy for actual slip direction on that surface (Wallace, 1951; Bott, 1959). Because the distribution of maximum resolved shear stress directions is sensitive to the stress state, specifically the stress ratio that generates the slip, it is further assumed that the directions of maximum resolved shear stress can be used as a proxy for the distribution of actual slip directions on variously oriented faults. Many stress inversion techniques utilize these assumptions, along with fault orientations and rake of slip directions, to estimate paleostress conditions (e.g., Angelier, 1979, 1984 and see Blenkinsop et al., 2006, for a review) and it forms the basis of stress inversion from earthquake focal mechanism data (e.g., Gephart and Forsyth, 1984). However, slip vector information is not generally available from such datasets as seismic reflection data (Orife et al., 2002) and the microseismic swarms commonly used in the oil and gas industry. Measured slip directions may also be unreliable representations of the direction of maximum shear stress (Lisle, 2013), and may be subject to local perturbations in the stress field generated by fault to fault interactions (Pollard et al., 1993) leading to an erroneous or poorly constrained inversion result. Here we use a stress inversion technique that employs the complementary assumption that slip tendency distribution, which also is sensitive to stress state (Morris et al., 1996), can be used as a proxy for the magnitude of slip on variously oriented fault surfaces (McFarland et al., 2012). This technique does not require knowledge of slip directions. However, because of the presence of well-exposed slickenline indicators on the fault surfaces described in this paper, we have a means of evaluating the consistency of the best-fit stress tensors derived from this new technique with those methods that use slip directions as the defining parameter. We apply this technique to sub-populations of faults to elucidate local stress perturbations resulting from displacement variation along-strike of a seismic-scale fault. 
We suggest that there is a conceptual link between slip tendency and fault displacementspecifically, faults in high slip tendency orientations are likely to experience more slip per slip increment, and to accumulate more slip over time than faults in low slip tendency orientations. This is not a linear relationship and is not likely to be continuous. For example, for a fault to form and slip, the resolved shear stress on the fault must exceed both the frictional resistance to sliding plus a threshold value that represents the cohesive strength of the rock. This intuitive way of thinking about stress and faulting is the basis of the Navier-Coulomb failure criterion (e.g., Price, 1966, p. 27):

$$
\tau=S+\mu \sigma
$$

where $\tau$ is the shear stress required to cause and slip the fault, $S$ is the cohesive strength of the rock, $\mu$ is the coefficient of internal friction of the rock, and $\sigma$ is the normal stress experienced by the slipped surface (Fig. 5).

Figure 5 about here

Whether or not slip occurs at a given shear stress depends on the value of $\sigma$ and the two rock-related constants $S$ (cohesive strength) and $\mu$ (coefficient of friction). There is also likely to be a range of threshold values contingent upon whether a new fracture surface is being formed, an existing fracture with no cohesion is slipping, or an existing fracture with some limited or residual cohesion is slipping (Fig. 5). Moreover, existing faults are likely to become conduits for fluid flow enhancing mineralogical reactions and locally increasing pore fluid pressure, both of which can lower the frictional resistance to sliding on a well-developed fault (e.g., Massironi et al., 2011; Collettini et al., 2009). Once formed, and in terms of stress magnitudes, a fault can accumulate slip more readily than it can propagate if the cohesion of the fault is less than the cohesion of the intact rock (Fig. 5). This reactivation relationship may not hold in the case of strain-hardening deformation, such as that which develops shear-induced deformation bands in unconsolidated clastic rocks (Aydin, 1978; Kaproth et al., 2010), and the rock mass will accumulate a series of deformation bands until a through-going fault develops in the system, each deformation band requiring essentially the same differential stress for failure. 
In a rock mass under critical stress conditions (i.e., poised for failure), faulting is likely to occur on surfaces with high slip tendency orientations. Depending on the nature of the stress tensor, this range of orientations could be narrow or broad (e.g., Morris and Ferrill, 2009; Fig. 6). There will therefore be a range of orientations represented in the population of faults that develops, and this range is a function of stress tensor characteristics and the material properties of the rock.

Figure 6 about here

Some threshold of shear stress is required either to initiate a fracture followed by slip or to reactivate an existing fracture by further slip. Therefore, not all slip tendencies will generate slip and there will be a lower bound below which faults can neither form nor slip, and so not all orientations will be represented in the fault population. For the example shown in Fig. 6, if a slip tendency of 0.60 is required for any slip to occur, then the fault population should be limited to the orientations represented by poles in the red colored regions of the lower hemisphere projections. However, if a slip tendency of 0.50 is sufficient to cause slip on some surfaces, then the fault population should include orientations represented by poles in the yellow through red colored regions (Fig. 6).

\subsection{Relationship between slip tendency and displacement}

Over time, and under stable stress conditions, we would expect that fault orientations experiencing persistently high slip tendency would accumulate more displacement than those with lower slip tendencies because they are likely to slip more frequently and with larger increments of slip, and that some orientations would not be represented at all. Conceptually, there would be a positive correlation between slip tendency and cumulative fault slip, but with a non-zero slip tendency intercept (Fig. 7). An individual slip surface that has a high slip tendency orientation will not necessarily have accumulated a large amount of displacement because it may have either been in the stress shadow of a larger slip surface or only have formed late in the deformation history and not experienced 
many slip increments. Because new slip surfaces may form at any time, surfaces with high slip tendencies may be represented by multiple displacement values from high to low, but surfaces with lower slip tendencies only will exhibit lower values of displacement. Hence, the distribution of points in displacement versus slip tendency parameter space should be a cloud with variable values of displacement for a given slip tendency, but with decreasing displacement range with decreasing slip tendency (Fig. 7).

Figure 7 about here

There is likely to be a sharp cutoff of the distribution at the slip tendency value that corresponds to the maximum strength of the rock under the deformation conditions in which the fault population formed. An evolving fault system would exhibit differing data envelopes as displacement accumulates (Fig. 7).

Assuming a constant stress tensor, the fault population will evolve by displacement accumulation on faults, linking of existing faults, and nucleation of new faults. We postulate that existing faults with the most favorable orientations (highest slip tendencies) would accumulate the most displacement over time. In addition, newly formed faults would likely display a distribution about a mean close to the most favorable orientations, with more and larger fault surfaces developing with optimal or near-optimal orientations, but the presence of local strength anomalies or pre-existing fractures would permit a number of smaller faults to develop at less optimal orientations. Interactions between faults developed as a result of overlap and the formation of relay structures could introduce a secondary population of faults reacting to local stress perturbations and with orientations at high angles to the dominant trend (e.g., Morris et al., 2014). Once linked into the predominant fault network, these secondary faults may continue to accumulate displacement but would have seemingly anomalous orientations (i.e., low slip tendency) with respect to the stress system responsible for the fault system as a whole. Such faults would be plotted in a diagram, such as Fig. 7, as having only moderate slip tendency (with respect to the overall stress state), but with relatively large displacements. Depending on the obliquity of these faults with those representing the dominant trend, 
they may serve to broaden the distribution or they may form a separate maximum that is indicative of the stress anomaly responsible for their initial formation.

The basic premise of the McFarland et al. (2012) fault-based stress inversion technique is that, following the logic of the previous two paragraphs, slip tendency can be used as a proxy for actual fault displacement, and that fault displacement can be very broadly defined. For example, in the case where mapping of seismic reflection data permits the characterization of fault gaps or overlaps, the fault gap can be represented by a surface consisting of triangular patches. Where dip-slip displacement is likely to be predominant, the orientations of these patches can be determined, and the areas can be used as a proxy for displacement. Other measures of displacement are earthquake magnitude (useful for both natural and induced seismicity, where nodal plane orientations are known), seismic semblance derived from passive microseismic monitoring (where surfaces are constructed from the density of seismic energy release; Lacazette et al., 2013), and actual measured displacement from faulted surfaces. The technique evaluates the ability of a candidate stress tensor to explain the pattern of displacement on surfaces of different orientations by quantifying the degree of agreement between the computed slip tendency values of the stress tensor and the corresponding measured displacement values for a set of observed surfaces. Stress inversion is then a matter of searching for the stress state that optimizes this measure of agreement. The technique can also take advantage of data gaps. If it can be assumed that orientations not represented in the dataset are the result of the physical absence of slipped surfaces with those orientations, then the search algorithm can be guided away from solutions that would cause such surfaces to exist. This is done by introducing null points into the dataset in orientations for which actual faults are absent (McFarland et al., 2012). Input data for the technique consists of a population of fault surface orientations together with some estimate of the fault displacement for that orientation, as discussed above.

\subsection{Stress inversion using faults adjacent to the Hidden Valley Fault}

We applied the McFarland et al. (2012) method to the footwall and hanging wall 
small-displacement fault populations described earlier in this paper, using 30 null points to guide the inversion. Input for the inversion consists of strike (right-hand-rule), dip, and displacement (here measured as bed displacement parallel to slickenlines) for patches of exposed fault surfaces. The results are illustrated in Fig. 8.

Figure 8 about here

The footwall and hanging wall solutions (Figs. 8A and B) are very similar to each other and to that of Ferrill et al. (2004 and 2012; Fig. 9), and represent a normal faulting stress regime with southeast or south-southeast-directed extension. We also inverted our fault slickenline data using the slip-direction based (Angelier, 1979) technique of Lisle (1988; Figs. $8 \mathrm{C}$ and $\mathrm{D}$ ). There is general agreement between the two inversion results, although the Lisle method generates solutions with high stress ratio $\left(\Phi=\frac{\left(\sigma_{2}-\sigma_{3}\right)}{\left(\sigma_{1}-\sigma_{3}\right)}\right)$ values. This is likely the result of the inability of the Angelier-Lisle method, and others that use slip direction as the basis for stress inversion, to discriminate between the relative importance of different slip directions. The McFarland et al. method uses displacement and its proxy slip tendency to recognize more important slip surfaces (larger displacements, higher slip tendencies) and weight them more heavily in finding a best fit solution.

Figure 9 about here

Further confidence in the (McFarland et al., 2012) inversion results is gained from the observation that there is a coherent pattern of displacement with respect to orientation, specifically fault strike (Figs. 4C and F), and this can be matched by a similarly coherent distribution of slip tendency with fault strike (Figs. 10A and B) for the best fit stress tensor. In addition, by cross-plotting displacement with slip tendency, as calculated for the best-fit stress state (Figs. 10C and D) a pattern similar to that predicted in Fig. 7 is obtained. Both Figs. 10C and D exhibit the salient features expected of a cross-plot of displacement and slip tendency for the situation where slip tendency and displacement are mutual proxies. 
Further, the availability of slickenline data for the faults in this study permits the calculation of the angular mismatch between slip directions predicted by the imposed stress state and the actual slip directions as measured in the field. This provides an opportunity to compare the results of stress inversion techniques making different but complementary assumptions about the links between aspects of the stress tensor and actual slip patterns in rocks. Based on the assumption that the maximum resolved shear stress on a surface is a good proxy for actual slip direction on that surface, minimizing angular mismatch for a dataset is used as the measure of goodness of fit in many stress inversion techniques (e.g., Gephart and Forsyth, 1984; Lisle, 1988). We are dealing with a normal faulting stress regime, so we consider that the orientation of $\sigma_{1}$ is near vertical, with a high degree of certainty. The principal uncertainties are likely the orientations of the horizontal stresses $\left(\sigma_{2}\right.$ and $\left.\sigma_{3}\right)$ and the magnitude of the intermediate principal compressive stress, $\sigma_{2}$, with respect to $\sigma_{1}$ and $\sigma_{3}$. This latter uncertainty is because there are no independent measures of its magnitude available, and it can vary between the limits $\sigma_{1}$ to $\sigma_{3}$ (e.g., Morris and Ferrill, 2009). The orientations of $\sigma_{2}$ and $\sigma_{3}$ are not independent of each other, so investigating the uncertainty of one will constrain the other. Varying these two parameters about the best-fit values and calculating the average angular mismatch for each scenario indicates that the best-fit estimates of the McFarland et al. (2012) method are very close to those corresponding to the minimum average angular mismatch values (Fig. 11).

Figure 11 about here

It is interesting to note that varying the orientation of the horizontal stresses generates a well-defined minimum in the angular mismatch, which is well matched by the McFarland et al. (2012)method (Figs. 11A and B), whereas variation in the magnitude of the intermediate principal stress does not produce such a well-defined minimum (Figs. 11C and D). This latter observation is in accord with Lisle's (2013) observation that the direction of maximum shear stress can be relatively insensitive to stress state, our data 
suggest that this likely occurs as $\sigma_{2}$ approaches $\sigma_{3}$ in magnitude (i.e., at low values of $\Phi=$ $\frac{\left(\sigma_{2}-\sigma_{3}\right)}{\left(\sigma_{1}-\sigma_{3}\right)}$; Figs. 11C and D).

Based on the estimated effective vertical stress $\left(\sigma_{\mathrm{v}}\right)$ discussed in section 4.1 (19 to 43 $\mathrm{MPa}$ ) it is possible to calibrate the stress states using the McFarland et al. (2012) inversion method. Interrogating the stress tensors for footwall and hanging wall fault populations indicates that the vertical (normal) stresses should be $98.63 \%$ of $\sigma_{1}$ (footwall) and $98.54 \%$ of $\sigma_{1}$ (hanging wall). Using the maximum and minimum values for effective $\sigma_{\mathrm{v}}$ and using a preferred overburden thickness of $1.5 \mathrm{~km}$, we calculate magnitudes for the three principal stresses (Table 1).

\subsection{Stress reorientation adjacent to the Hidden Valley Fault}

Although the best-fit stress states derived for the footwall and hanging wall of the Hidden Valley fault are in close agreement both with each other, and with previous stress states inferred for the Balcones Fault System (e.g., Ferrill et al., 2004), field observations and orientation plots (Section 2; Figs. 2 and 3) indicate the presence of fault subpopulations that do not perfectly fit this model. In the footwall pavement, faults with traces almost perpendicular to the main Hidden Valley fault trend are visible (Figs. 3A, 4A and C), and the hanging wall pavement contains faults with strikes of around $285^{\circ}$ (Figs. 3A, 4D and F). Filtering out the fault slip surfaces that have strikes within $\pm 15^{\circ}$ of the main Hidden Valley fault strike $\left(060^{\circ}\right)$, and inverting the remaining faults for the best-fit stress states indicates normal faulting stress regimes with extension directions of northeast-southwest in the footwall and north-northeast-south-southwest in the hanging wall (Fig. 12).

Figure 12 about here

We attribute these nonregional stress orientations to along-fault-strike components of extension, as documented by Morris et al. (2014). The subpopulations of faults responding to this reorientation of stress generally have smaller displacements than faults oriented to accommodate regional extension, and they are not uniformly developed either 
along the strike of the Hidden Valley fault or on either side of it. Localized stress reorientation is likely related to displacement gradients along the major fault and related along-strike extension (Ferrill and Morris, 2001; Morris et al., 2014), and this is supported by the presence of a breached relay structure east-northeast (Ferrill et al., 2011) along the main fault trace from the two sets of pavements described in this study (Fig. 3A). Displacement on the Hidden Valley fault decreases from $60 \mathrm{~m}$ of total throw southsouthwest of the pavements to $\sim 21 \mathrm{~m}$ on the northern bounding fault of the relay and $\sim 34$ $\mathrm{m}$ on the southern bounding fault of the relay (Ferrill et al., 2011). There is a corresponding along-fault-strike component of dip of as much as $7^{\circ}$ in the footwall adjacent to the Hidden Valley fault (Fig. 3B), and a northeast-directed (fault-oblique) dip of about $5^{\circ}$ in the hanging wall. These variations in dip from horizontal can generate a dip-parallel extension (e.g., Morris et al., 2014), and we interpret this to be responsible for the subpopulations of faults that depart from the regional trend.

These local anomalies in stress orientations can be masked by large amounts of otherwise consistent data. In the case presented here, subpopulations of faults developed in anomalous (with respect to a regional pattern) stress states were discovered by careful inspection of field data.

\section{Conclusions}

Small-displacement normal faults exposed adjacent to a seismic scale normal fault show strong preferred strike orientations (Fig. 3A), and patterns of displacement that are orientation dependent (Figs. 4A, C, D, and F) and predominantly dip-slip in nature (Figs. 4B and E). Applying a stress inversion technique that assumes slip tendency and displacement to be mutual proxies for these fault populations yields results that are consistent with other stress estimates for both the region and the locality. In addition, slip directions predicted by these stress estimates are in close agreement with measured slip directions (as slickenlines) on the surfaces of the faults.

Stress inversion techniques are typically based on the assumption that the pattern of 
maximum resolved shear stresses developed in a stress state is a proxy for the measured slip directions on faults. The stress state found by a trial-and-error search that gives the best-fit between the computed and observed patterns is presumed to be the stress state responsible for the formation of the slip surfaces measured. Slip directions are not always measurable in geologic datasets, so a complementary assumption is that the pattern of slip tendency developed in a stress state is a proxy for the measured displacements on faults, and a trial-and-error search of stress states to minimize the difference between the slip tendency and the observed displacement patterns forms the basis of the inversion. Our results suggest that slip tendency is a useful tool for stress inversion, may be a superior criterion for estimating stress states, and can be an independent check on results where slip direction information is available. In common with other stress inversion methods, the technique we use here is essentially scaleindependent and can be applied to seismic scale faults as well as the small-displacement faults described in this work. The ability to invert stress states without requiring slip direction data can provide a useful alternative method for stress estimation in areas that are tectonically active or that are experiencing induced seismic activity. In such cases the nodal plane orientations of seismic events can be weighted with a function of magnitude as a proxy for displacement, and then a best-fit stress tensor can be found by trial-anderror.

\section{Acknowledgements}

We thank Justin Leonard and Aaron Price for programming 3DStress ${ }^{\circledR}$, and Kevin Smart and English Pearcy for helpful reviews of this manuscript. Jaynellen Ladd and the Guadalupe Blanco River Authority granted us access to the Canyon Lake Spillway Gorge. Scott Wilkins and Cristiano Collettini provided detailed and constructive reviews that greatly improved the final manuscript. This work was supported by Southwest Research Institute's Internal Research and Development Program awards R8018 and R8456. 


\section{References}

Abbott, P.L., 1966. The Glen Rose section in the canyon reservoir area, Comal County, Texas: Master of Arts Thesis, University of Texas, Austin, Texas, 146 p.

Anderson, E.M., 1951. The dynamics of faulting and dyke formation with applications to Britain: Edinburgh, United Kingdom, Oliver and Boyd, 206.

Angelier, J., 1975. Sur l'analyse de mesures recueillies dans sites faillés: L'utilité d'une confrontation entre les méthodes dynamiques et cinèmatiques. Comptes rendus Academie Sciences, Paris D281, 1805-1080.

Angelier, J., 1979. Determination of the mean principal directions of stresses for a given fault population. Tectonophysics 56, T17-T26.

Angelier, J., 1984. Tectonic analysis of fault slip datasets. Journal of Geophysical Research 89, 5835-5848.

Aydin, A., 1978. Small faults formed as deformation bands. Pure and Applied Geophysics 116, 913-930.

Blenkinsop, T., Lisle, R., Ferrill, D. A., 2006. Introduction to the special issue on new dynamics in palaeostress analysis. Journal of Structural Geology 28, 941-942.

Bott, M.H.P., 1959. The mechanics of oblique slip faulting. Geological Magazine 96, 109-117.

Byerlee, J., 1978. Friction of rocks. Pure and Applied Geophysics 116, 615-626.

Collettini, C., Niejmeijer, A., Viti, C., Maroni, C., 2009. Fault zone fabric and fault weakness. Nature 462, 907-910. 
Collettini C., Sibson R.H. 2001, Normal faults, normal friction? Geology 29, 927-930.

Collettini, C., Trippetta, F., 2007. A slip tendency analysis to test mechanical and structural control on aftershock rupture planes. Earth and Planetary Science Letters 255, 402-413.

Collins, E.W., Hovorka, S.D., 1997. Structure map of the San Antonio segment of the Edwards aquifer and Balcones fault zone, south-central Texas: Structural framework of a major limestone aquifer: Kinney, Uvalde, Medina, Bexar, Comal, and Hays counties: University of Texas at Austin, Bureau of Economic Geology, Miscellaneous Map 38, scale 1:250,000, 2 sheets.

Collins, E.W., 2000. Geologic map of the New Braunfels, Texas, 30×60 minute quadrangle: geologic framework of an urban-growth corridor along the Edwards Aquifer, south-central Texas: The University of Texas at Austin Bureau of Economic Geology Miscellaneous Map No. 39, 28 p., scale 1:100,000, 1 sheet.

Cope, E.D., 1880. On the zoological position of Texas: U.S. Natural History Museum Bulletin 17, 51.

Ferrill, D.A., Morris, A.P., 2001. Displacement gradient and deformation in normal fault systems. Journal of Structural Geology 23, 619-638.

Ferrill, D.A., Morris, A.P., 2008. Fault zone deformation controlled by carbonate mechanical stratigraphy, Balcones fault system, Texas. AAPG Bulletin 92, 359380.

Ferrill, D.A., Sims, D.W., Waiting, D.J., Morris, A.P., Franklin, N., Schultz, A. L., 2004. Structural framework of the Edwards aquifer recharge zone in south-central Texas. Geological Society of America Bulletin 116, 407-418. 
659

660

661

662

663

664

665

666

667

668

669

670

671

672

673

674

675

676

677

678

679

680

681

682

683

684

685

686

687

688

689

Ferrill, D.A., Morris, A.P., Sims, D.W., Green, R., Franklin, N., Waiting, D.J., 2008. Geologic Controls on Interaction Between the Edwards and Trinity Aquifers, Balcones Fault System, Texas. South Texas Geological Society Bulletin, April 2008, 21-45.

Ferrill, D.A., Morris, A.P., McGinnis, R.N., 2009. Crossing conjugate normal faults in field exposures and seismic data. AAPG Bulletin 93, 1471-1488.

Ferrill, D.A., Morris, A.P., McGinnis, R.N., Smart, K.J., Ward, W.C., 2011. Fault zone deformation and displacement partitioning in mechanically layered carbonates: The Hidden Valley fault, central Texas. American Association of Petroleum Geologists Bulletin 95, 1383-1397.

Ferrill, D.A., McGinnis, R.N., Morris, A.P., Smart, K.J., 2012. Hybrid failure: Field evidence and influence on fault refraction. Journal of Structural Geology 42, 140150.

Flawn, P.T., Goldstein Jr., A., King, P.B., Weaver, C.E., 1961. The Ouachita system: Bureau of Economic Geology, University of Texas at Austin Publication 6120, 401 p.

Foley, L.L., 1926. Mechanics of the Balcones and Mexia faulting. AAPG Bulletin $10: 12,1261-1269$.

George, W.O., 1952. Geology and ground-water resources of Comal County, Texas: U.S. Geological Survey Water-Supply Paper 1138, 60.

Gephart, J.W., Forsyth, D., 1984. An improved method for determining the regional stress tensor using earthquake focal mechanism data: application to the San Fernando earthquake sequence. Journal of Geophysical Research 89, 9305-9320. 
690

691

692

693

694

695

696

697

698

699

700

701

702

703

704

705

706

707

708

709

710

711

712

713

714

715

716

717

718

719

720

Hill, R.T., 1889. A brief description of the Cretaceous rocks of Texas and their economic value, in E. T. Dumble, ed., First annual report of the Geological Survey of Texas: Texas Department of Agriculture, Insurance, Statistics, and History, Austin, Texas, 105-141.

Hill, R.T., 1890. Classification and origin of the chief geographic features of the Texas region. The American Geologist, January 1890, 6, 9- 29.

Kaproth, B.M., Cashman, S.M., Marone, C., 2010. Deformation band formation and strength evolution in unlithified sand: The role of grain breakage. Journal of Geophysical Research, 115, B12103, B12103, doi:10.1029/2010JB007406.

Lacazette, A., Vermilye, J., Fereja, S., Sicking, C., 2013. Ambient fracture imaging: A new passive seismic method: SPE 168849 / URTeC 1582380. Proceedings, First Unconventional Resources Technology Conference. Society of Petroleum Engineers.

Lamb, M.P., Fonstad, M.A., 2010. Rapid formation of a modern bedrock canyon by a single flood event. Nature Geoscience, DOI: 10.1038/NGEO894, 5 p.

Lisle, R. J., 1988. ROMSA: A Basic program for palaeostress analysis using faultstriation data. Computers in Geoscience 14, 255-259.

Lisle, R.J., Srivastava, D.C., 2004. Test of the frictional reactivation theory for faults and validity of fault-slip analysis. Geology 32, 569-572.

Lisle, R.J., 2013. A critical look at the Wallace-Bott hypothesis in fault-slip analysis. Bulletin de la Société Géologique de France 184, 299-306.

Maclay, R.W. Small, T. A.,, 1983. Hydrostratigraphic subdivisions and fault barriers of 
the Edwards aquifer, south-central Texas, U.S.A. Journal of Hydrology 61, 127146.
Massironi, M., A. Bistacchi, L. Menegon, 2011, Misoriented faults in exhumed metamorphic complexes: Rule or exception?: Earth and Planetary Science Letters, v. 307, p. 233-239.

McFarland, J.M., Morris, A.P., Ferrill, D.A., 2012. Stress inversion using slip tendency. Computers \& Geosciences 41, 40-46.
McGinnis, R.N., Ferrill, D.A., Smart, K.J., Morris, A.P., Higuera-Diaz, C., Prawica, D, 2015. Pitfalls of Using Entrenched Fracture Relationships: Fractures in Bedded Carbonates of the Hidden Valley fault Zone, Canyon Lake Gorge, Comal County, Texas. AAPG Bulletin, in press.
Morris, A.P., Ferrill, D.A., 2009. The importance of the effective intermediate principal stress $\left(\sigma^{\prime} 2\right)$ to fault slip patterns. Journal of Structural Geology 31, 950-959.

Morris, A.P., Ferrill, D.A., Henderson, D.B., 1996. Slip tendency and fault reactivation. Geology 24, 275-278.
Morris, A.P., McGinnis, R.N., Ferrill, D.A., 2014. Fault displacement gradients on normal faults and associated deformation. American Association of Petroleum Geologists Bulletin 98, 161-1184.

Murray, G.E., 1956. Relationships of Paleozoic structures to large anomalies of coastal element of eastern North America. Gulf Coast Association of Geological Societies Transactions 6, 13-24.

Murray, G.E., 1961. Geology of the Atlantic and Gulf Coastal province of North America: New York, Harper and Brothers, 692. 
Orife, T., Arlegui, L., Lisle, R., 2002. DIPSLIP: a QuickBasic stress inversion program for analyzing sets of faults without slip lineations. Computers and Geosciences 28, $775-781$.

\author{
Pollard, D. D., Saltzer, S. D., Rubin, A. M., 1993. Stress inversion methods: are they \\ based on faulty assumptions? Journal of Structural Geology 15, 1045-1054.
}
Price, N.J., 1966. Fault and joint development in brittle and semi-brittle rock: Oxford, Pergamon Press, 176.

Ramsay, J.G., 1967. Folding and fracturing of rocks. McGraw Hill, New York, 568.

Ramsay, J. G., Lisle, R., 2000. The Techniques of Modern Structural Geology, Volume 3: Applications of Continuum Mechanics in Structural Geology. Academic Press, $1061 \mathrm{p}$.

Streit, J.E., Hillis, R.R., 2004. Estimating fault stability and sustainable fluid pressures for underground storage of CO2 in porous rock. Energy 29, 1445-1456.

Terzaghi, K. von, 1936. The shearing resistance of saturated soils and the angle between the planes of shear. In: First International Conference on Soil Mechanics, vol. 1. Harvard University, Cambridge, MA, 54-56.

Ward, W.C., Ward, W.B., 2007. Stratigraphy of the middle part of Glen Rose Formation (Lower Albian), Canyon Lake Gorge, central Texas, in R. W. Scott, ed., Cretaceous rudists and carbonate platforms: Environmental feedback: SEPM Special Publication 87, 193-210.

Wallace, R.E., 1951. Geometry of shearing stress and relationship to faulting. Journal of Geology 59, 111-130. 
784 Weeks, A.W., 1945. Balcones, Luling, and Mexia fault zones in Texas: AAPG Bulletin 29, 1733-1737.

786

Young, K., 1972. Mesozoic history, Llano region, in V. E., Barnes, W. C. Bell, S. E. Clabaugh, P. E. Cloud Jr., R. V. McGehee, P. U. Rodda, and K. Young, eds., Geology of the Llano region and Austin area, field excursion: The University of Texas at Austin Bureau of Economic Geology Guidebook 13, 154. 


\section{Figure Captions}

Figure 1. Map of the Balcones Fault System in south-central Texas with fault traces colored according to their slip tendencies. Slip tendency analysis was performed using 3DStress ${ }^{\mathrm{TM}}$ v. 1.3.3 (see Ferrill et al., 2004) based on mapped faults of Collins and Hovorka (1997). Black outline represents the Canyon Lake Gorge area. Modified from figure 5 of Ferrill et al. (2004).

Figure 2. Small-displacement $(<1 \mathrm{~m})$ faults cutting Glen Rose Limestone (herein named Pavement 86.6) in Canyon Lake Gorge, south-central Texas. Lineations on faults are slickenlines indicating fault slip direction. The ground surface in the fore- and middleground is a single stratigraphic horizon $(86.6 \mathrm{~m}$ in the measured section of Ferrill et al., 2011). Hammer for scale.

Figure 3. (A) Map of field measurement locations color-coded by fault displacement. Insets are length-weighted rose diagrams of fault traces for the footwall and hanging wall fault populations described in the text. A small selection of bedding orientations is included for context. Blue arrow shows the line of section in B. (B) Longitudinal, strikeparallel section along the Hidden Valley fault illustrating the along-fault-strike dips of the footwall and hanging wall cutoffs, as described in the text. Upper has no vertical exaggeration, lower has $3 x$ vertical exaggeration.

Figure 4. Orientation and displacement data for measured fault populations. (A) Lower hemisphere equal angle projection of poles to measured footwall slip surfaces, colorcoded by displacement in meters. The pole (open star) to and the great circle (solid black great circle) of the average orientation of the Hidden Valley fault are shown for reference. (B) Plot of displacement versus count for all measured footwall fault surfaces, points are colored according to the same scale as A. (C) Plot of fault displacement versus strike of all measured footwall fault patches. Color-coding as in A. (D), (E), and (F) are similar plots for measured fault surfaces in the hanging wall of the Hidden Valley fault.

Figure 5. Mohr circle construction showing stress states required for slip within normal 
faulting regime on (a) newly developing failure surfaces, (b) existing surfaces with limited cohesion, and (c) existing surfaces with no cohesion. $\sigma_{\mathrm{v}}$ is assumed to be $\sigma_{1}$ (normal faulting) and therefore essentially constant for a given depth, magnitude of $\sigma_{3}$ at any point in the rock mass would then determine whether slip would occur. Also shown is the relationship between the various values of slip tendency required for slip on optimally oriented surfaces.

Figure 6. Range of fault strikes for which appropriately dipping faults will experience $90 \%$ of the maximum slip tendency plotted versus $\Phi$ in a normal faulting stress regime. Insets are slip tendency plots for $\Phi=0,0.5$, and 1 for the case where $\sigma_{3}^{\prime}=30 \%$ of $\sigma^{\prime}{ }_{1}$ (Morris and Ferrill, 2009).

Figure 7. Conceptual form of the relationship between slip tendency and observed (cumulative) fault displacement. Data from measured fault surfaces could fall anywhere within the shaded area.

Figure 8. (A) and (B) Slip tendency plots of the best-fit stress states for the footwall and hanging wall fault populations using the method of McFarland et al. (2012). (C) and (D) Slip tendency plots of the best-fit stress states for the footwall and hanging wall fault populations using the method of Lisle (1988). Table gives orientations of principal stresses and magnitudes as a percentage of $\sigma_{1}$ magnitude.

Figure 9. Comparison of the principal stress orientations estimated for the Balcones Fault Zone (Ferrill et al., 2004), a small portion of the footwall damage zone within the Hidden Valley fault Zone (Ferrill et al., 2012), and from this study.

Figure 10. (A) and (B) Slip tendency as a function of strike. The slip tendency values are calculated for the best-fit stress states for each pavement, as illustrated in Fig. 8 A and B. (C) and (D) Displacement cross-plotted with calculated slip tendency for the best-fit stress states for each pavement. 
856 Figure 11. Sensitivity of average angular mismatch (angle between predicted slip by 857 modeled stress state and actual measured slickenline directions) with respect to $\sigma_{3}$ (and $858 \sigma_{2}$ ) orientations and relative magnitudes of the principal stresses. (A) Footwall and (B) 859 hanging wall plots for variation of $\sigma_{3}$ direction about the best-fit orientation. (C) 860 Footwall and (D) hanging wall plots for variation of the $\sigma_{2}$ magnitude with respect to 861 best-fit $\sigma_{1}$ and $\sigma_{3}$ magnitudes, expressed as percentages of $\sigma_{1}$. Best-fit values are from 862 the analysis shown in Fig. 8 using McFarland et al. (2012).

863

864 Figure 12. Slip tendency plots of the stress states inverted using the subpopulations of 865 faults not parallel to the main Hidden Valley fault in the footwall (A) and hanging wall 866 (B).

867

868 Table 1.

869 Estimated magnitudes of principal stresses using inverted percentages and a range of 870 possible overburden depths during faulting.

871

872

873

874

875

876 


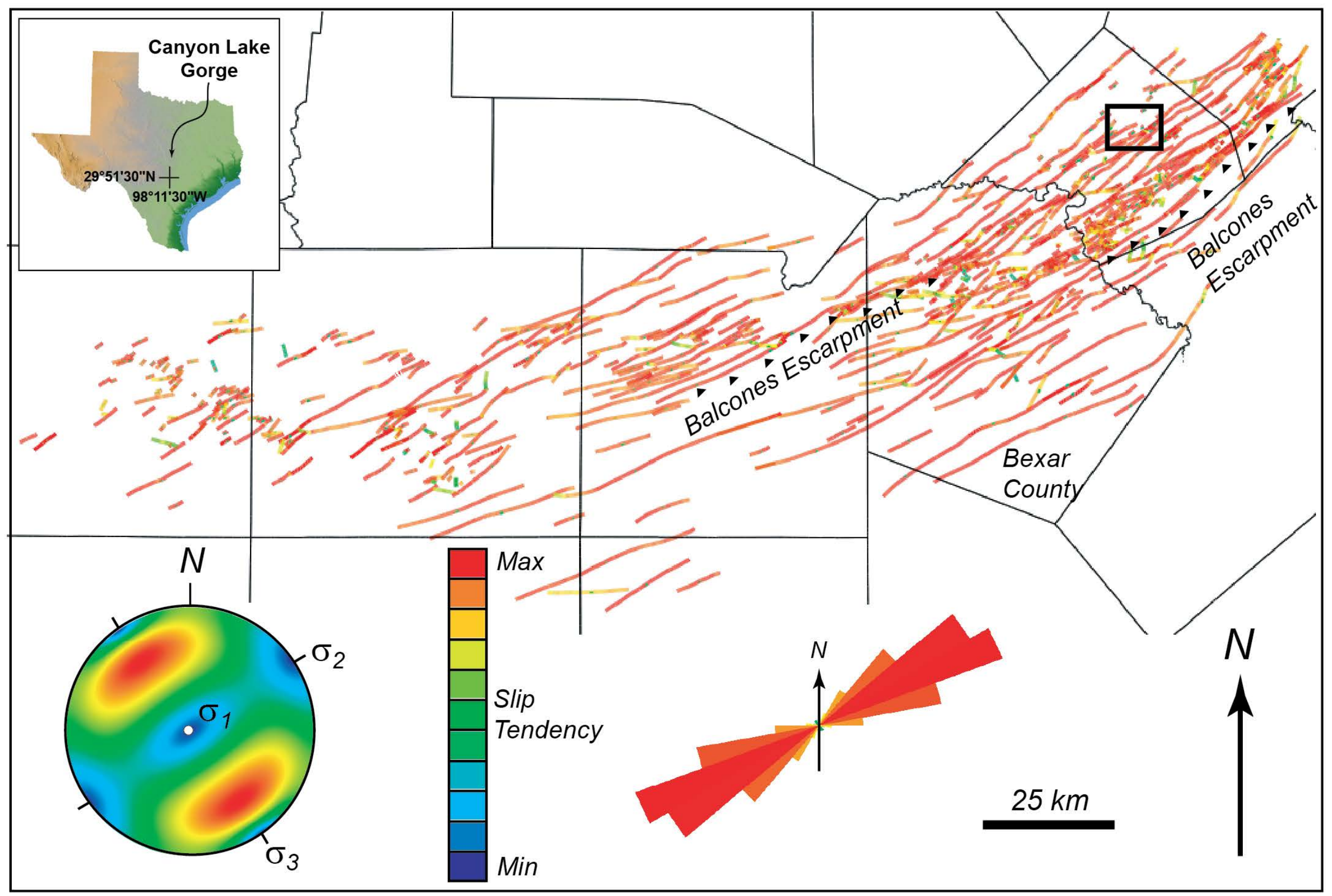



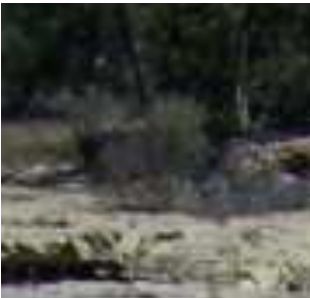

$x^{-}$

-

4

1.t.

$=0$

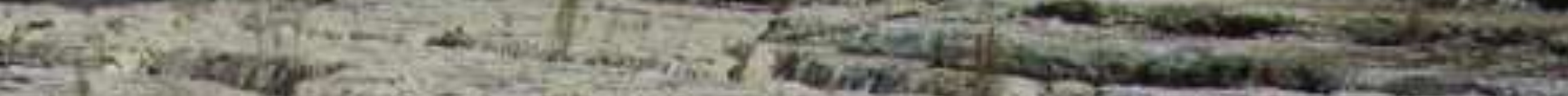

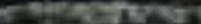

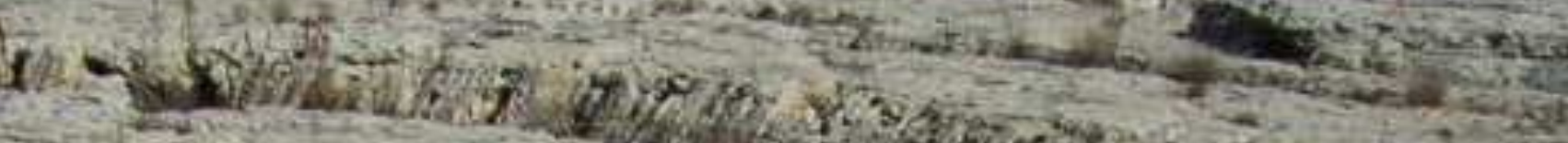

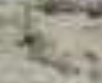

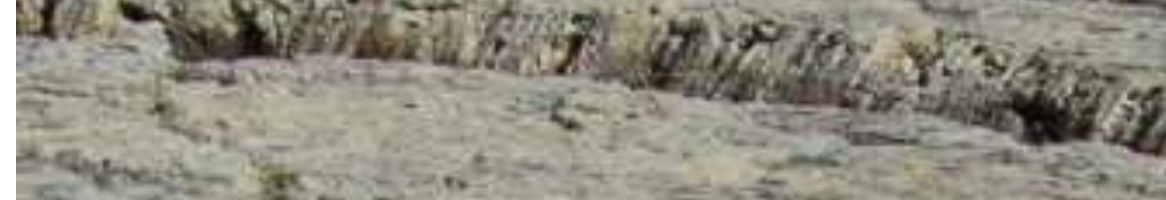

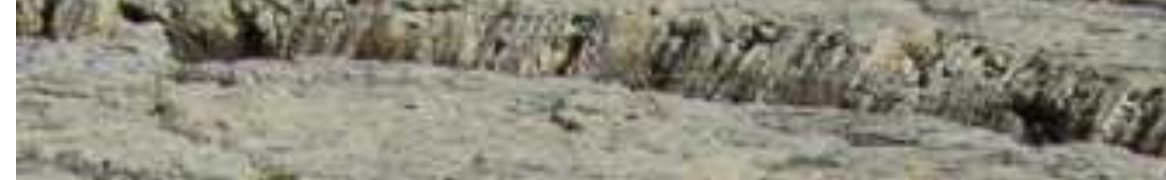

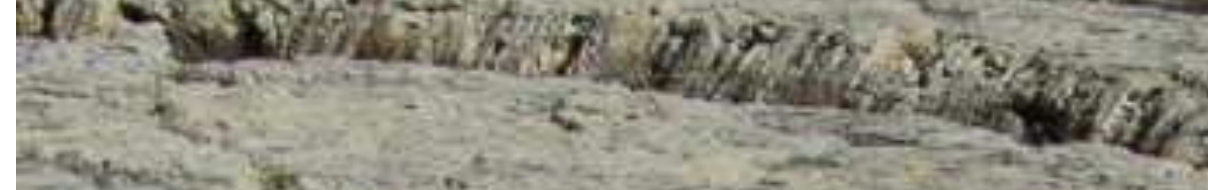

(2)

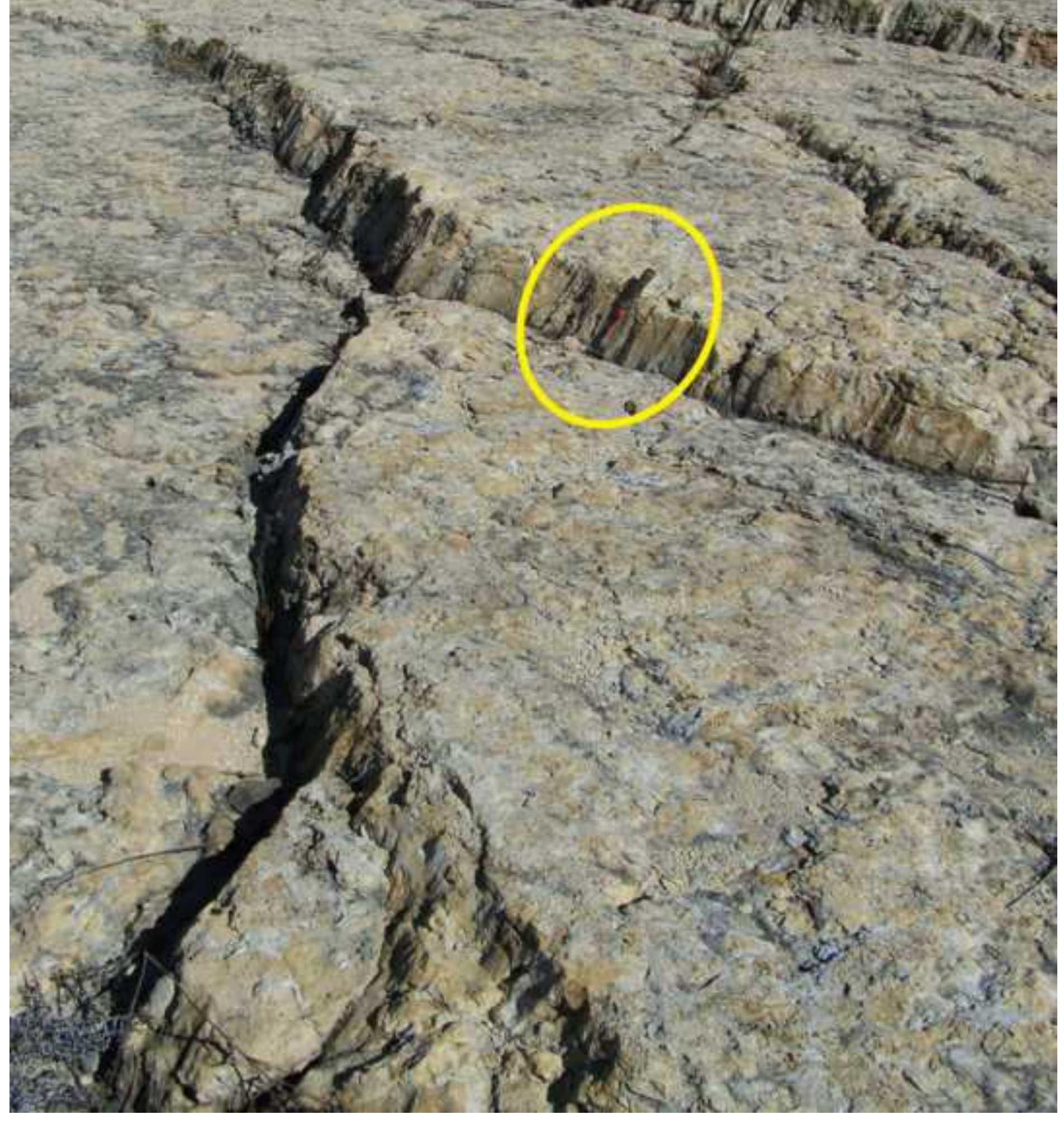




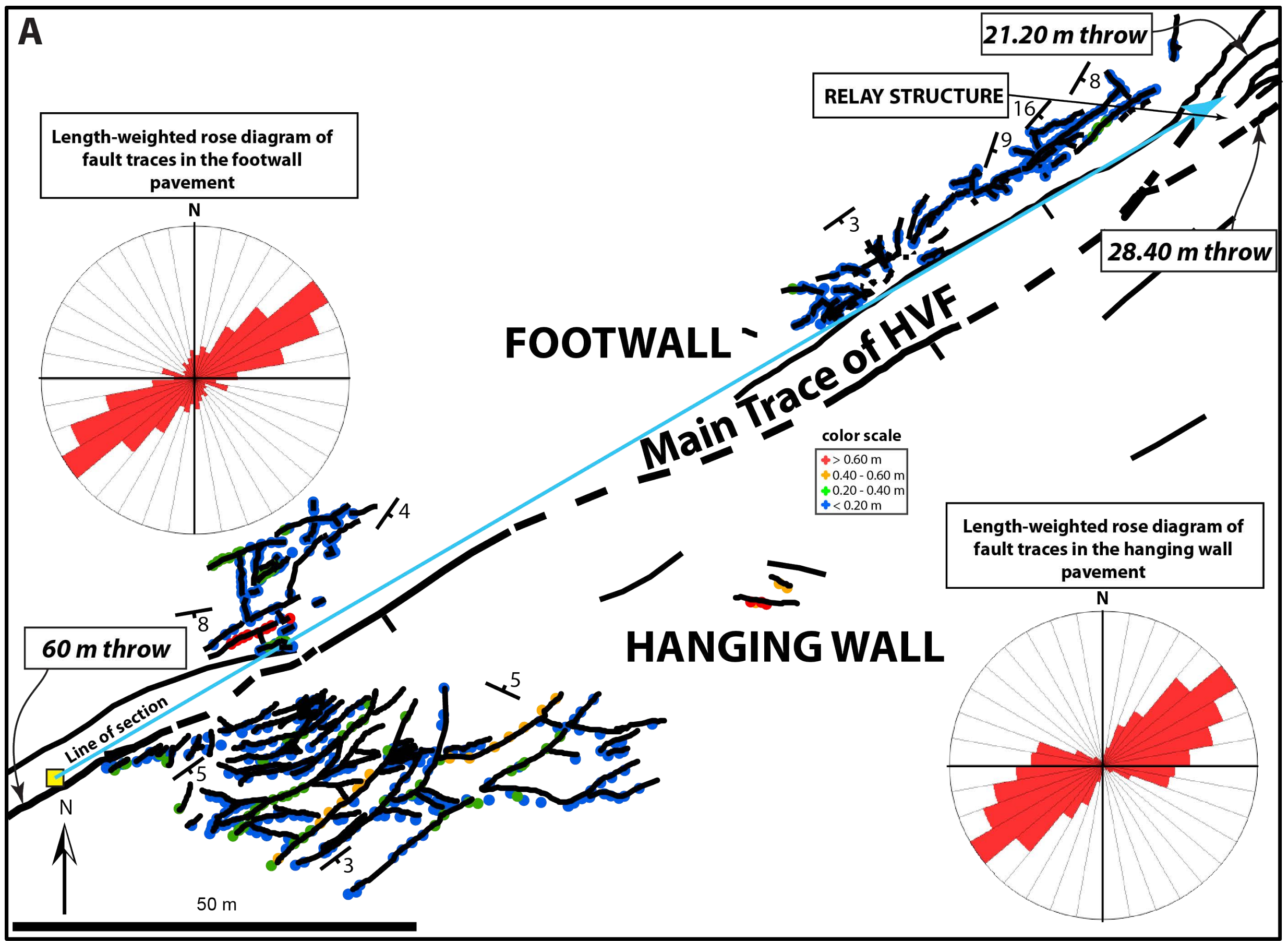




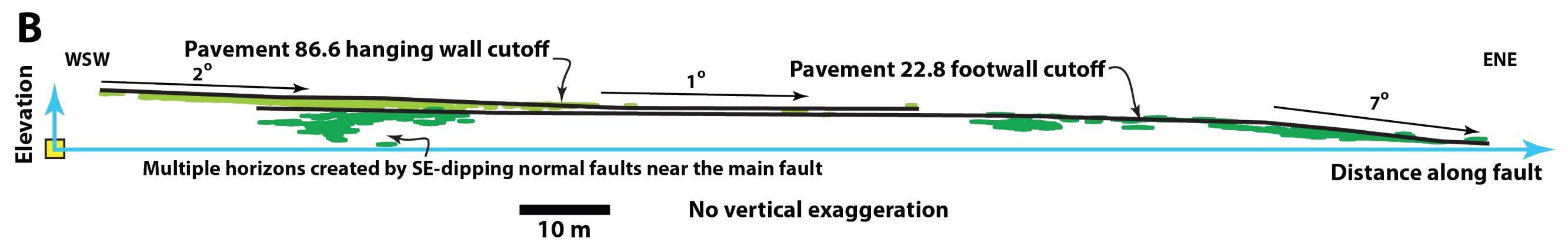

$\begin{array}{r}\text { Pavement 86.6 } \\ \hline \text { Pavement 22.8 }\end{array}$

WSW

Pavement 86.6 hanging wall cutoff

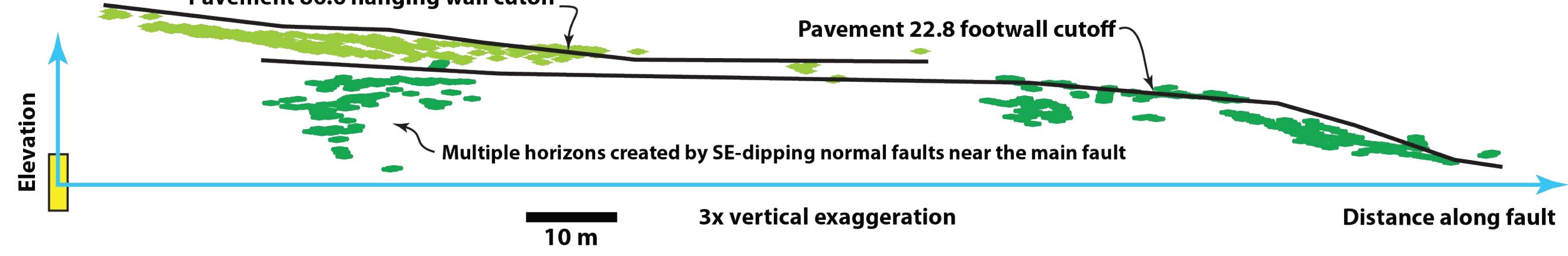




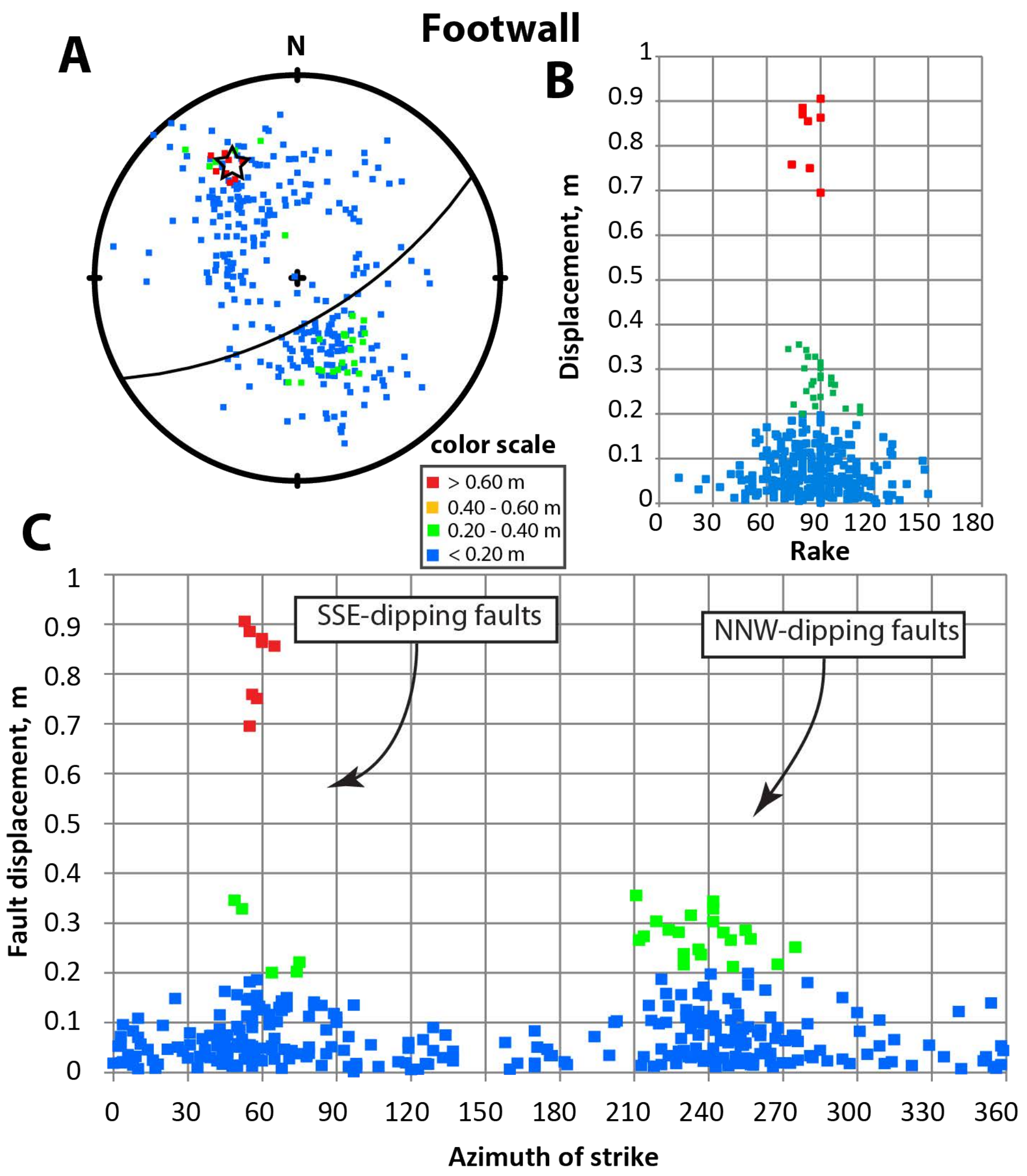




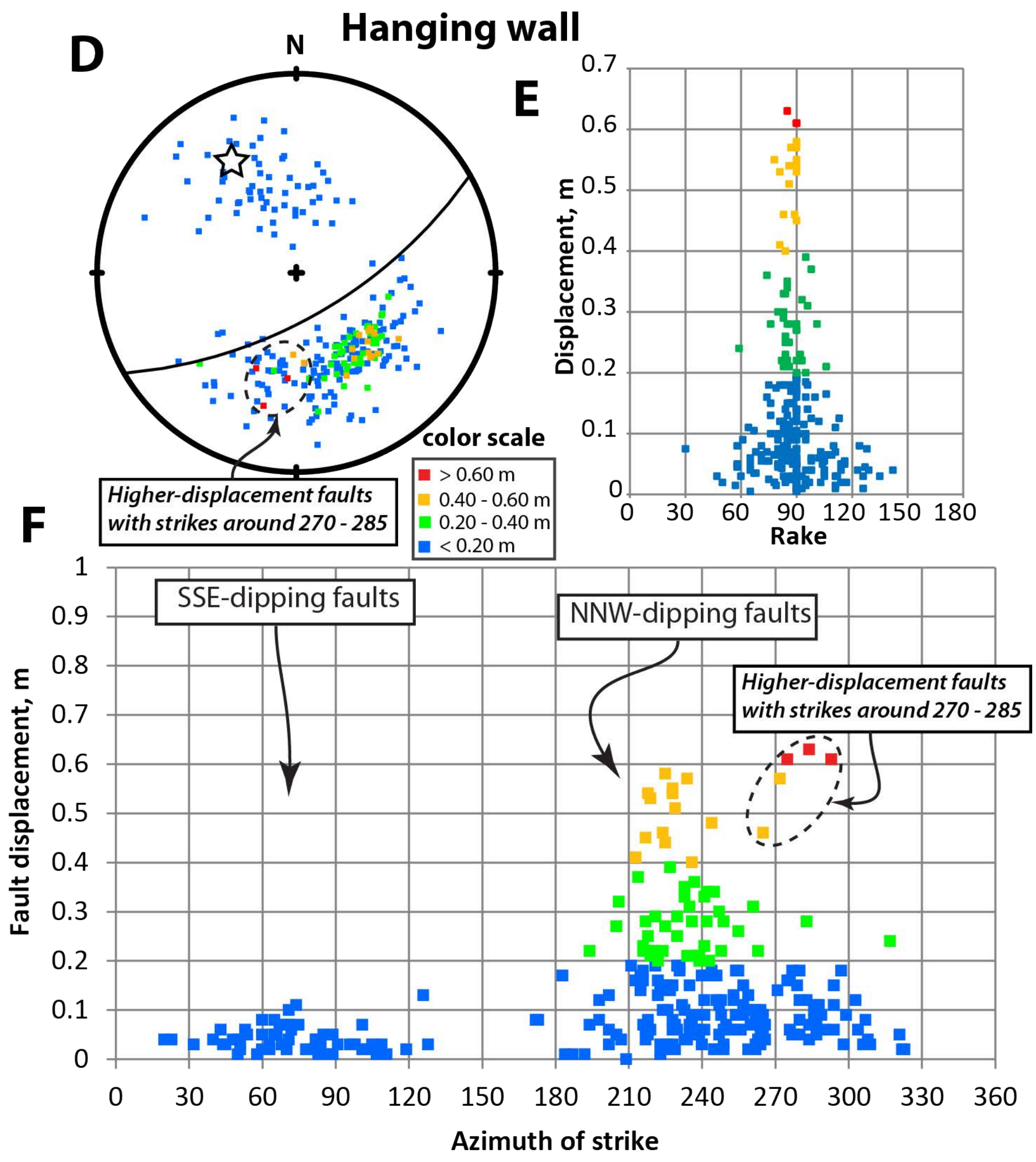




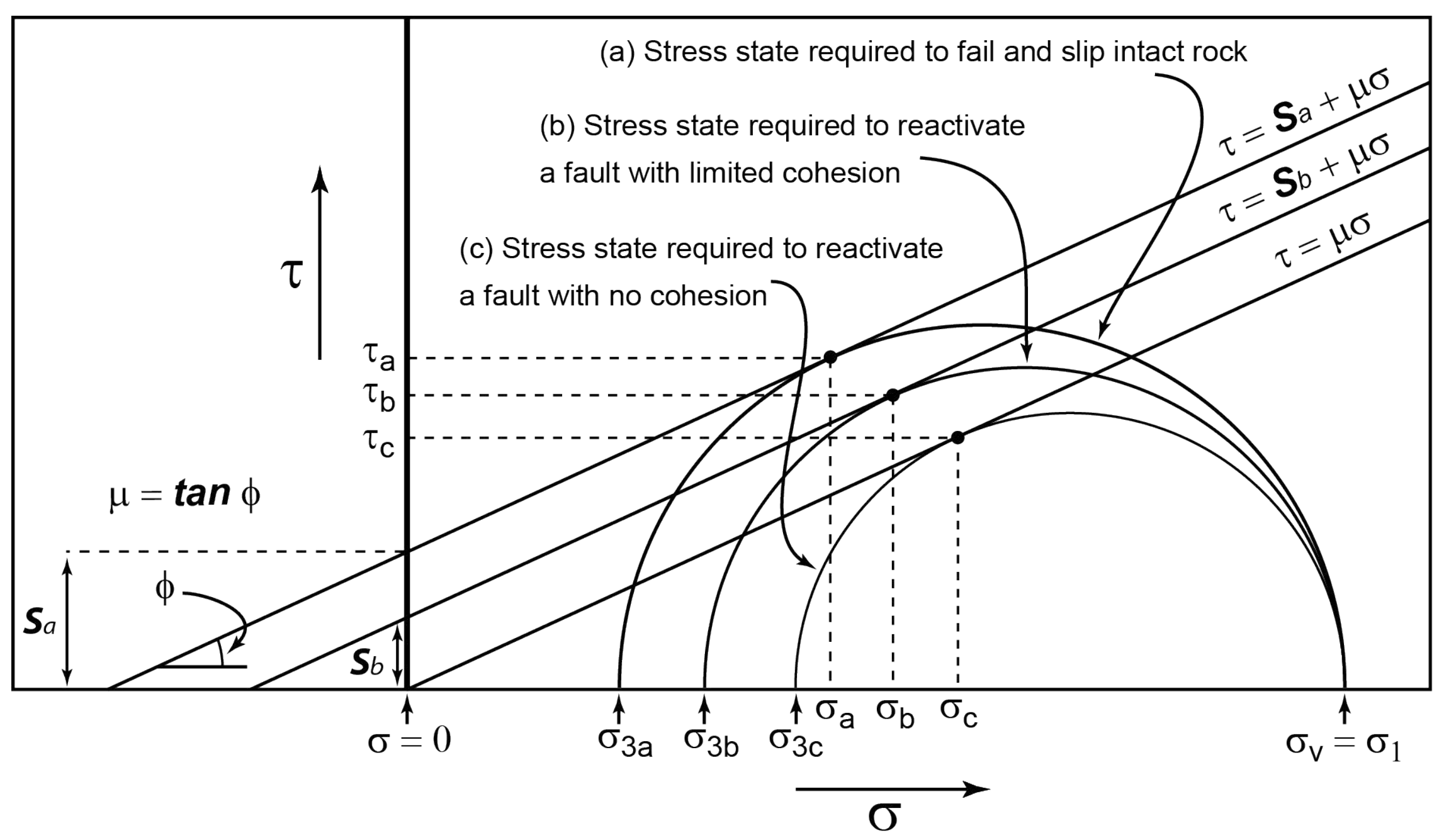

(a) Slip tendency for case a, $T_{s a}=\tau_{a} / \sigma_{a}$

(b) Slip tendency for case b, $\left.\boldsymbol{T}_{s b}=\tau_{\mathrm{b}} / \sigma_{\mathrm{b}}\right\}$ Such that $\boldsymbol{T}_{s a}>\boldsymbol{T}_{s b}>\boldsymbol{T}_{s c}$; and $\boldsymbol{T}_{s c=\mu}=\tan \phi$

(c) Slip tendency for case c, $T_{s c}=\tau_{c} / \sigma_{c}$ 


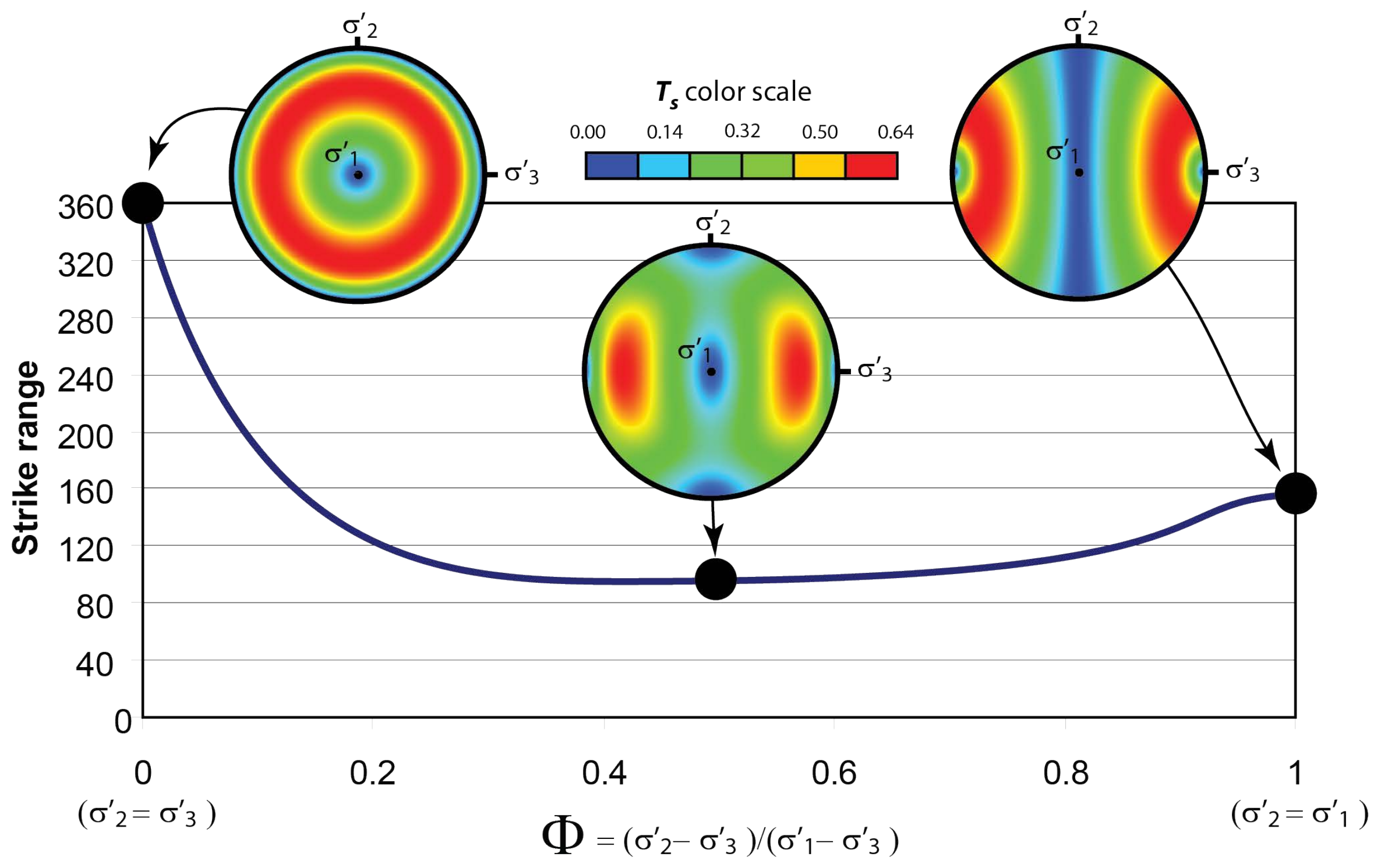




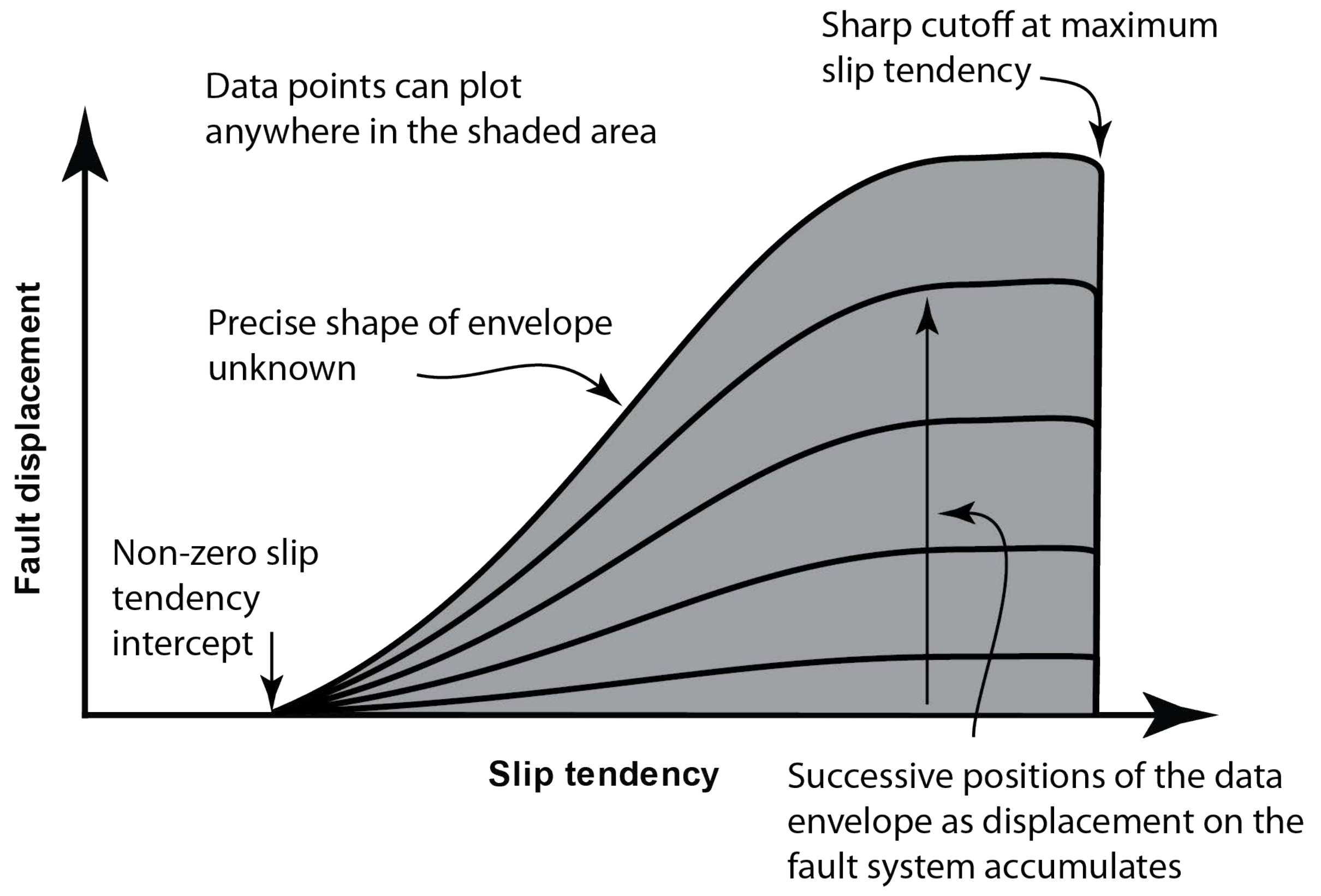


A

Footwall faults

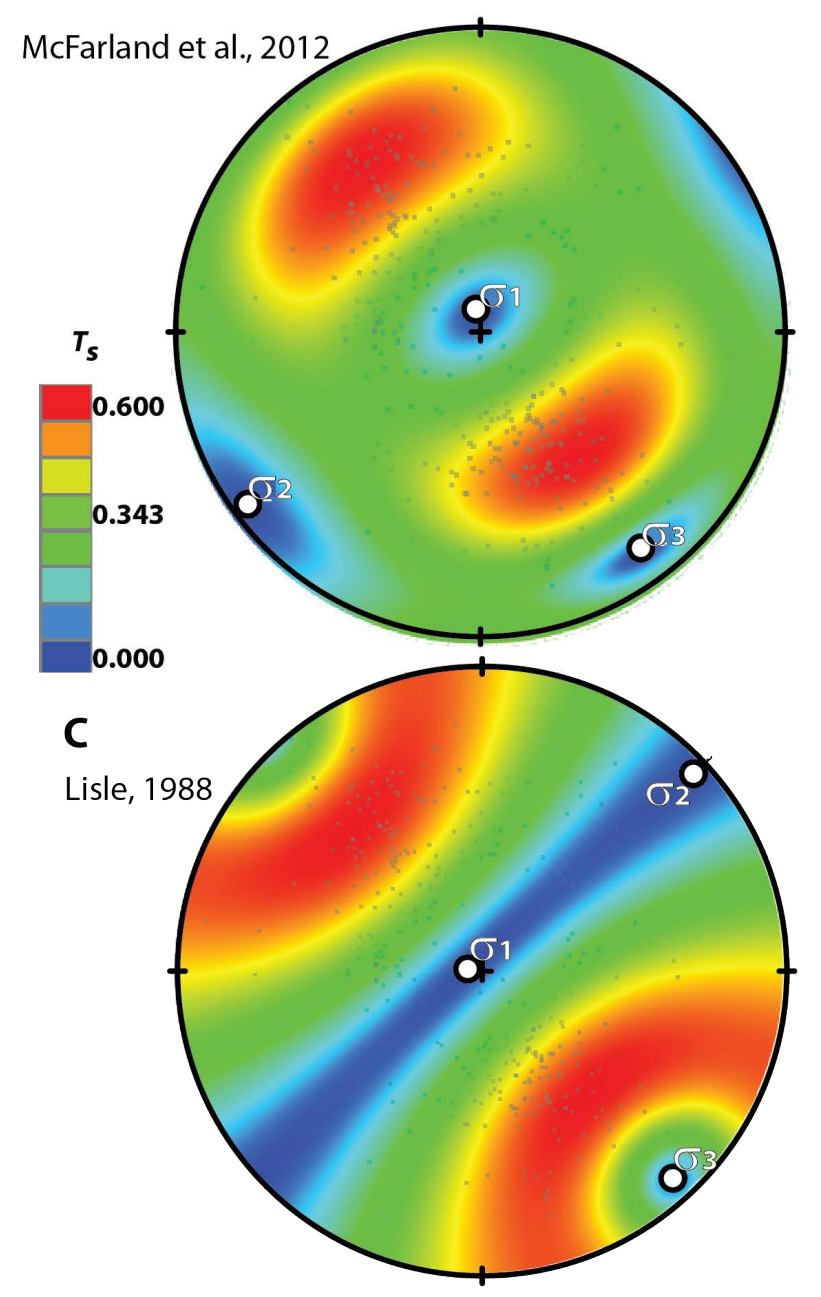

B

Hanging wall faults

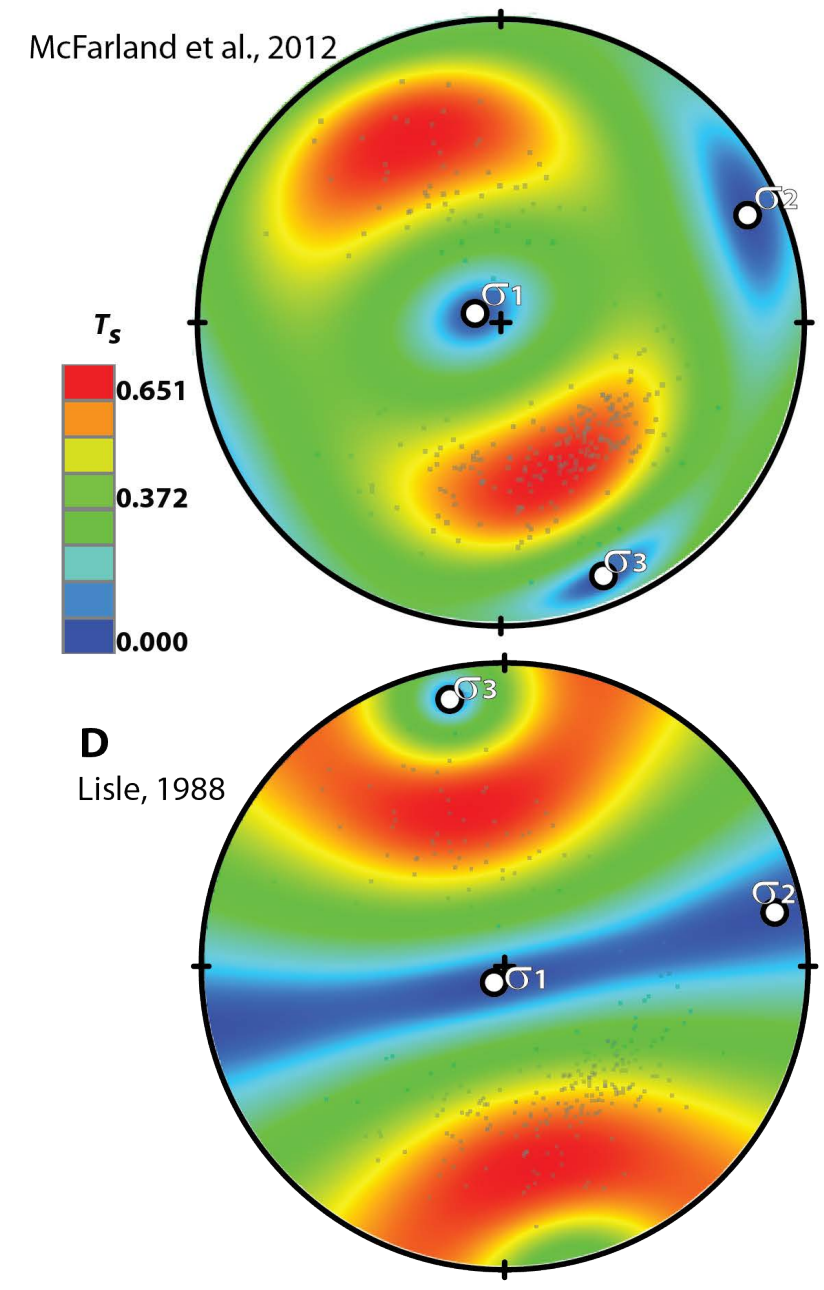

\begin{tabular}{|l|c|c|c|c|c|c|c|c|c|}
\hline & \multicolumn{4}{|c|}{$\sigma_{1}$} & \multicolumn{4}{c|}{$\sigma_{2}$} & \multicolumn{3}{c|}{$\sigma_{3}$} \\
\hline & magnitude & direction & plunge & magnitude & direction & plunge & magnitude & direction & plunge \\
\hline Footwall & $100 \%$ & 349 & 81 & $54 \%$ & 054 & 04 & $32 \%$ & 143 & 08 \\
\hline Footwall - Lisle & $100 \%$ & 287 & 85 & $93 \%$ & 047 & 02 & $32 \%$ & 137 & 04 \\
\hline Hanging wall & $100 \%$ & 290 & 82 & $49 \%$ & 067 & 07 & $29 \%$ & 158 & 05 \\
\hline Hanging wall - Lisle & $100 \%$ & 213 & 82 & $89 \%$ & 079 & 05 & $29 \%$ & 348 & 06 \\
\hline
\end{tabular}




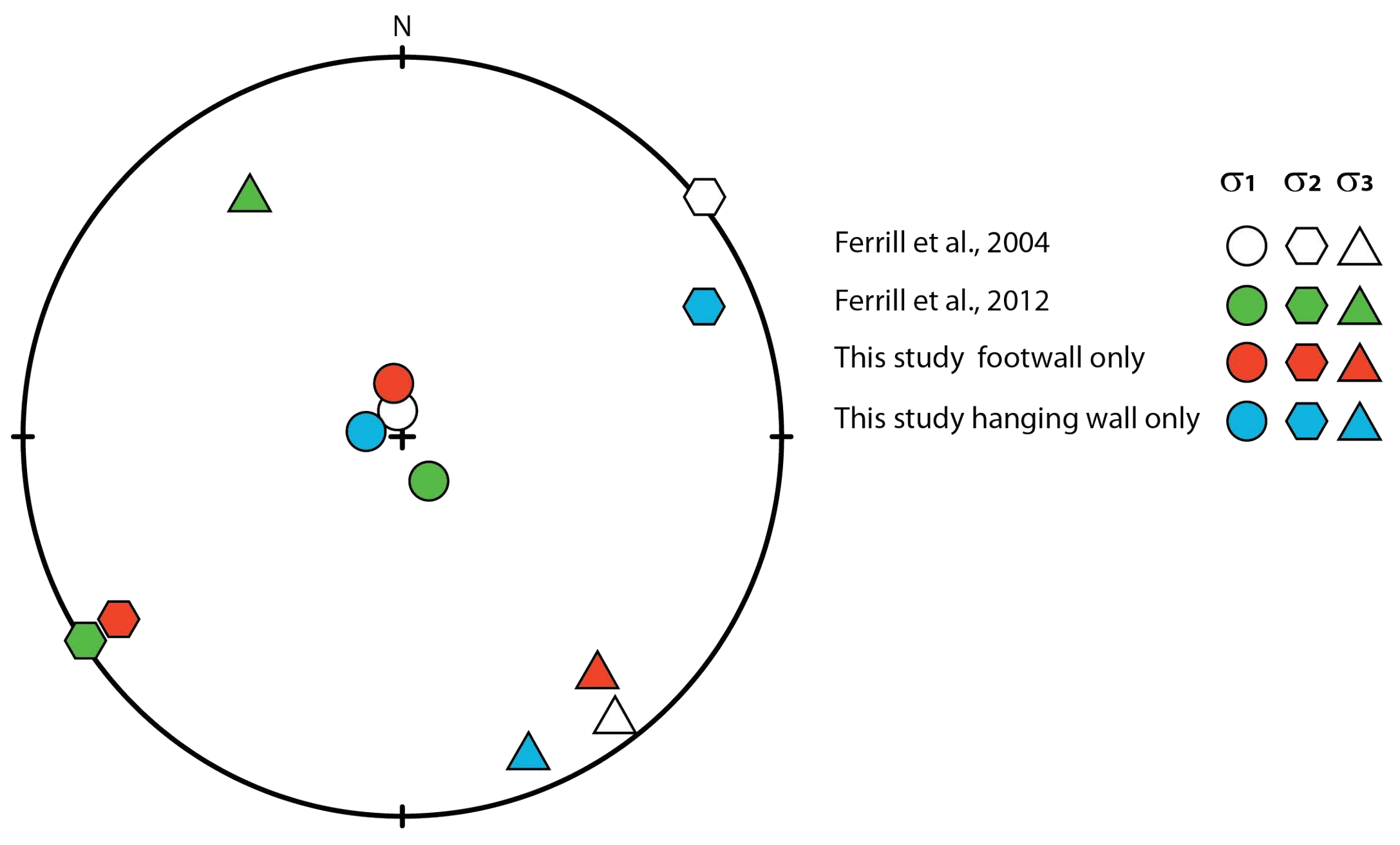


A

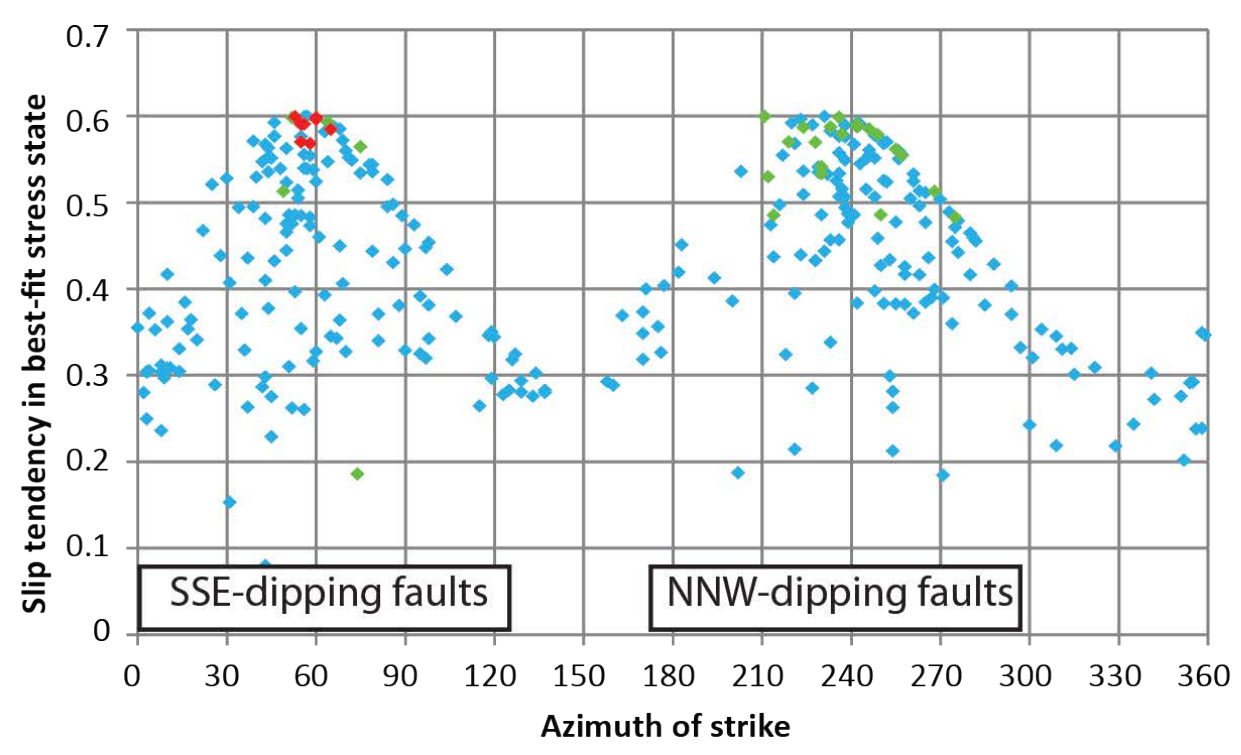

Footwall faults

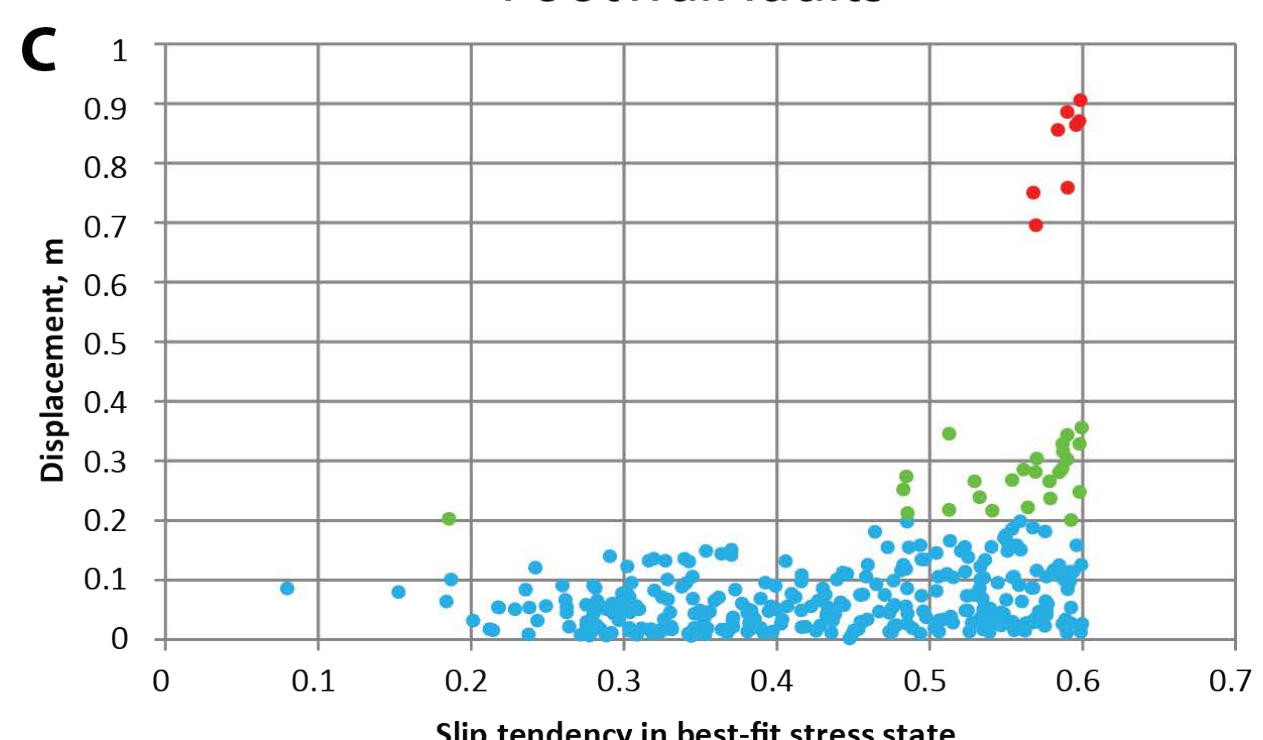

B Hanging wall faults

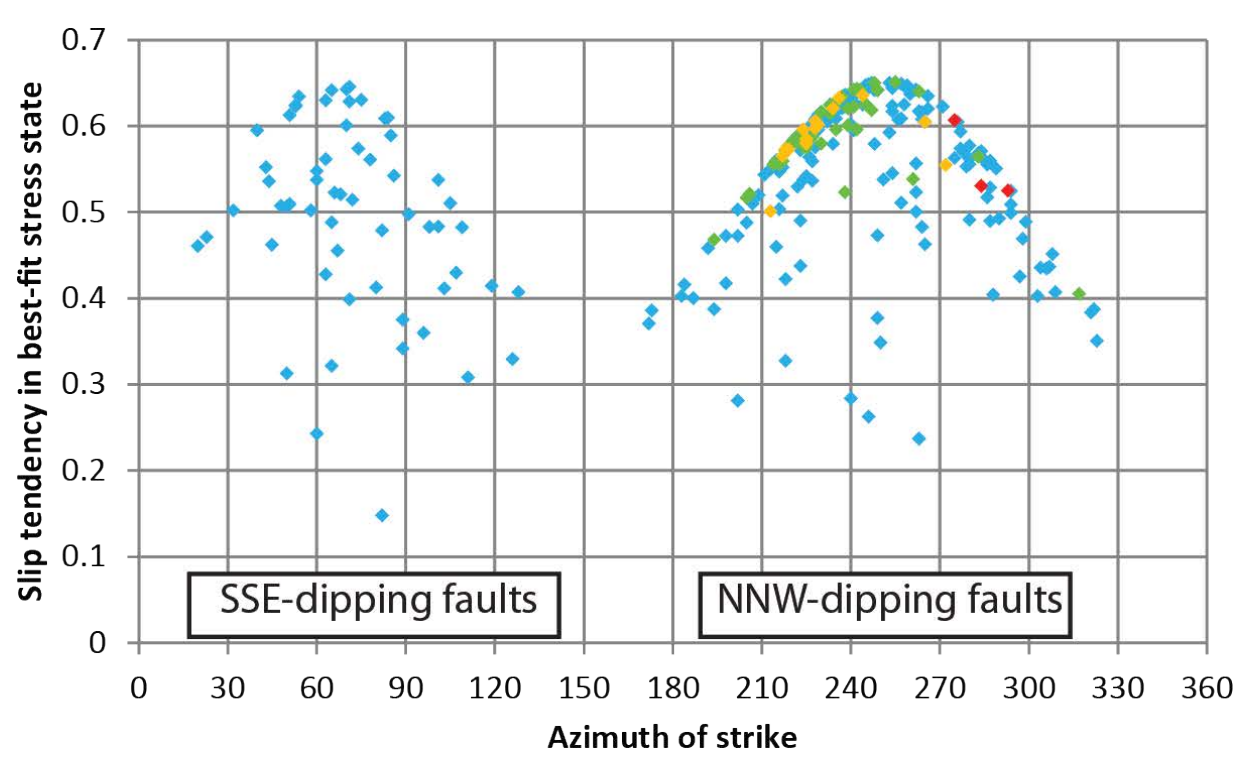

Hanging wall faults

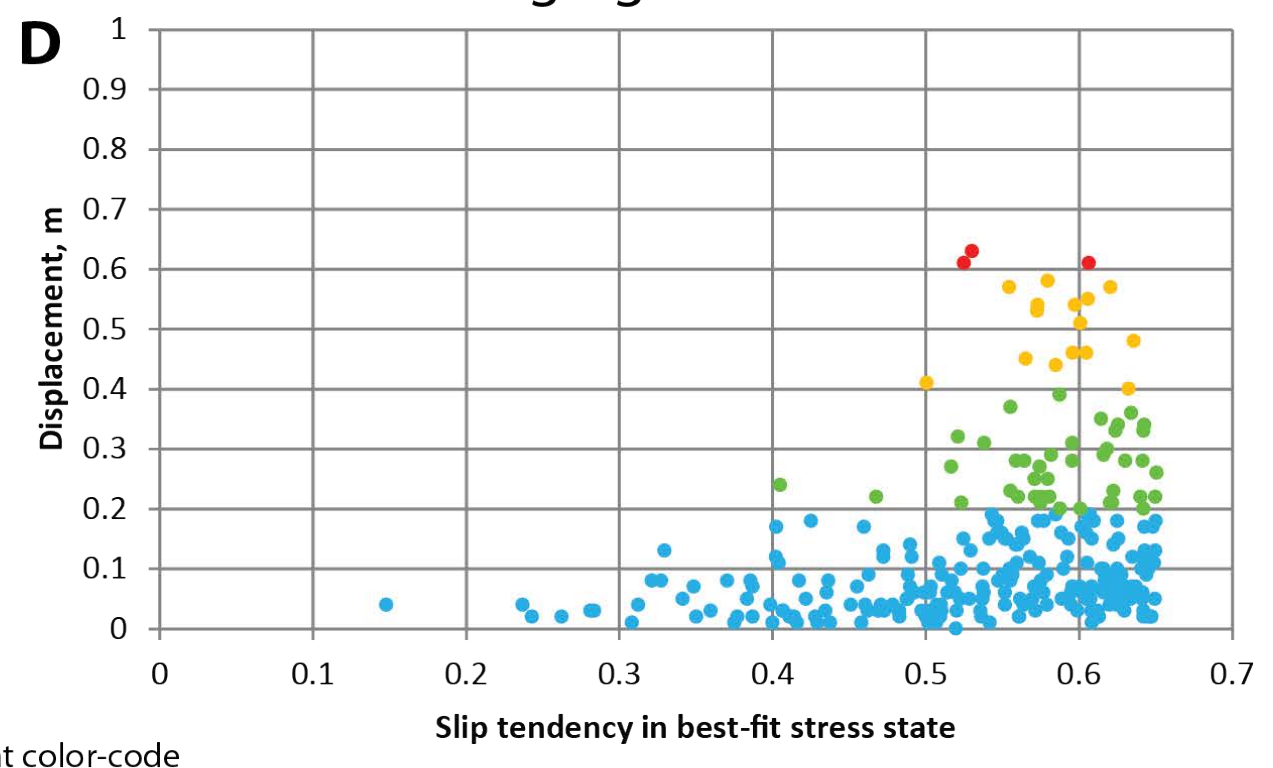


A

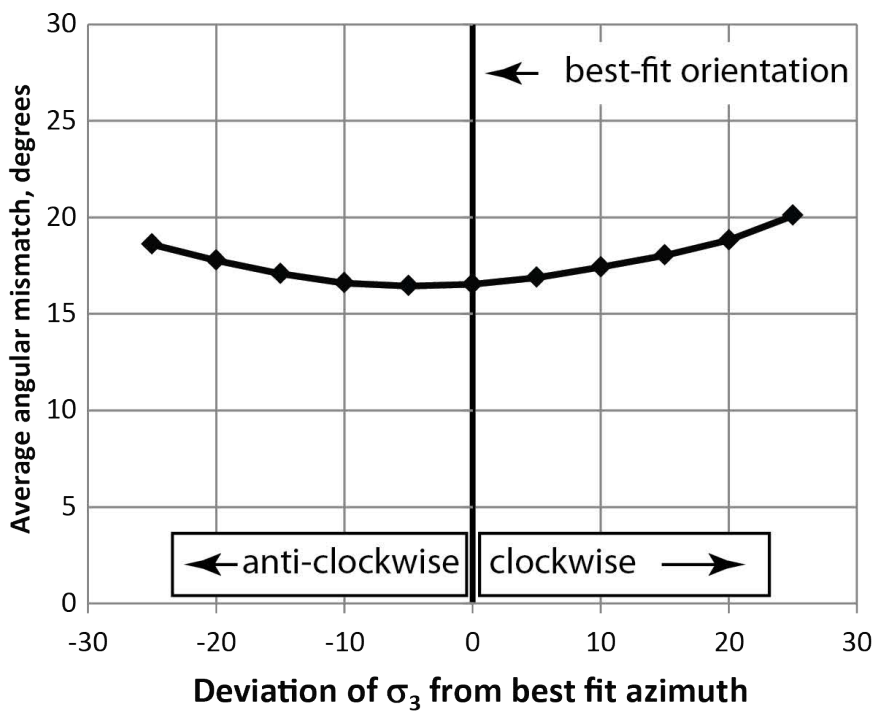

C

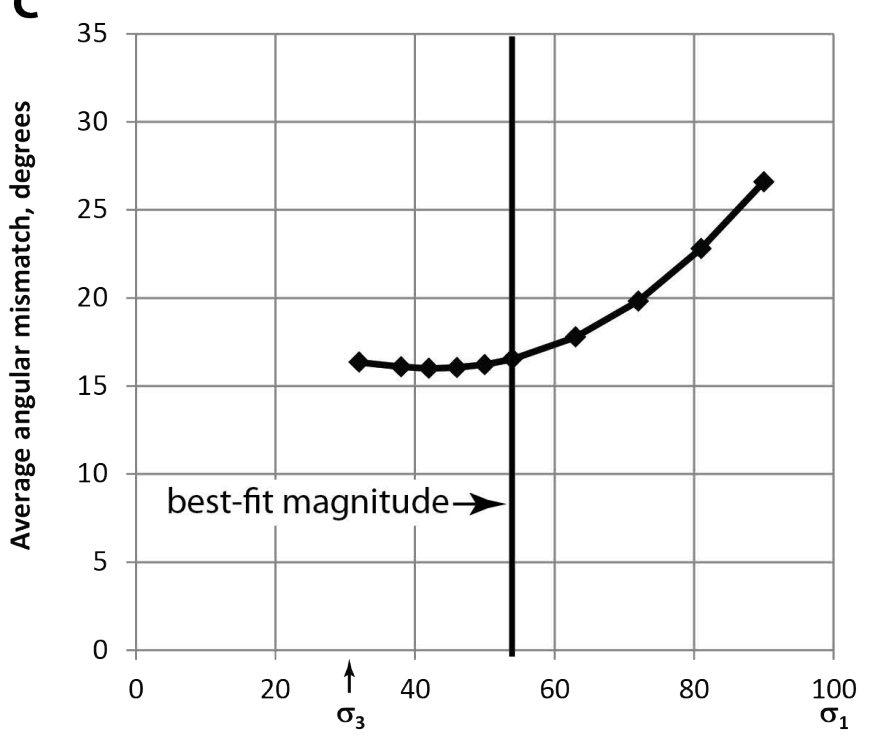

Magnitude of $\sigma_{2}$ as a percentage of $\sigma_{1}$
B Hanging wall

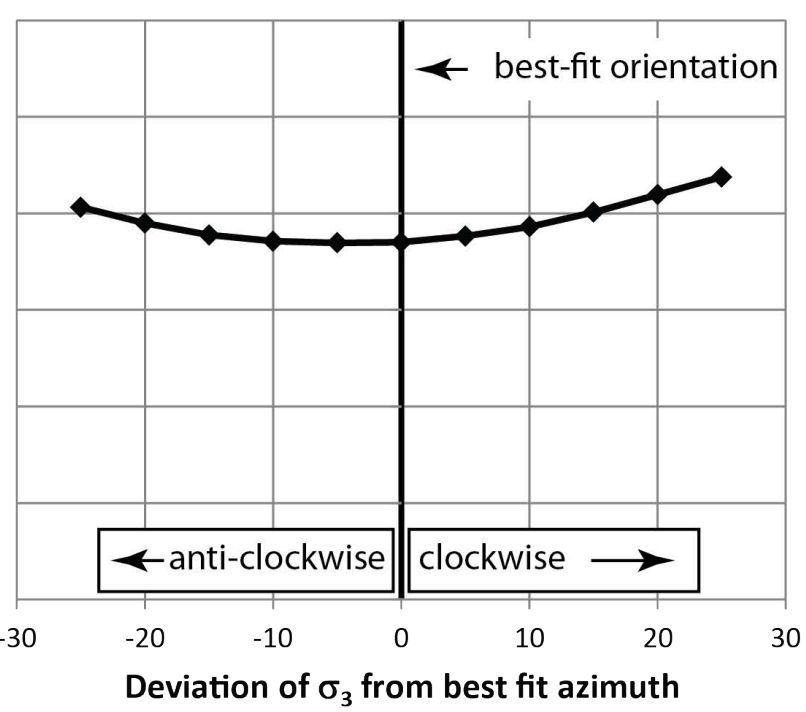

D

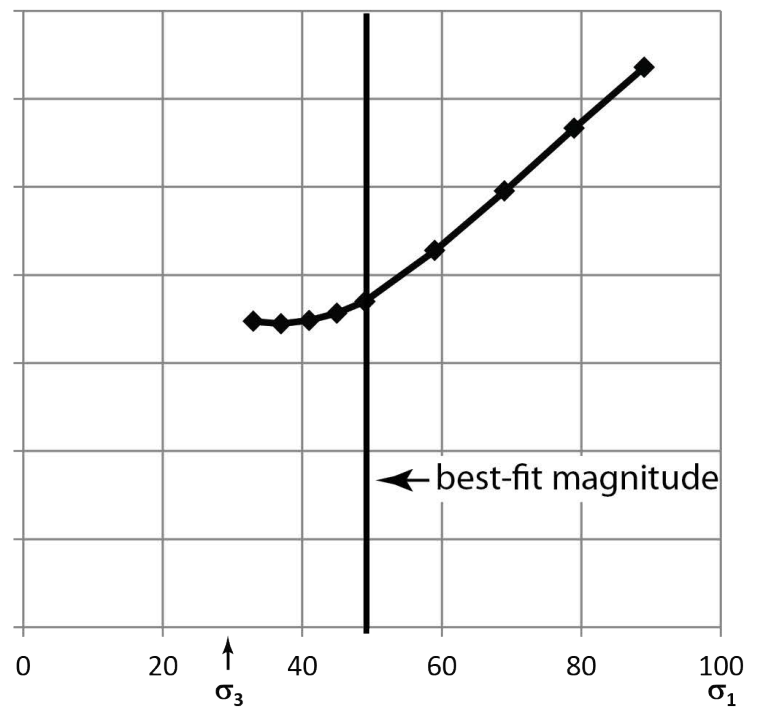

Magnitude of $\sigma_{2}$ as a percentage of $\sigma_{1}$ 
A

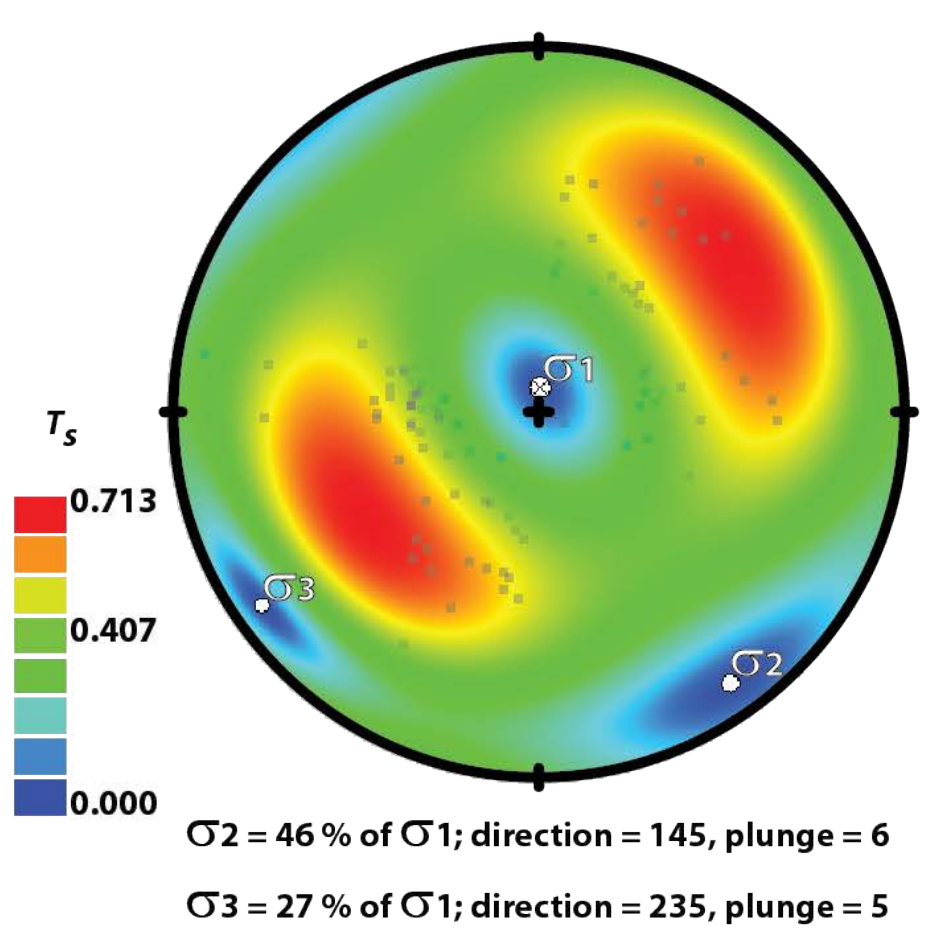

B Hanging wall

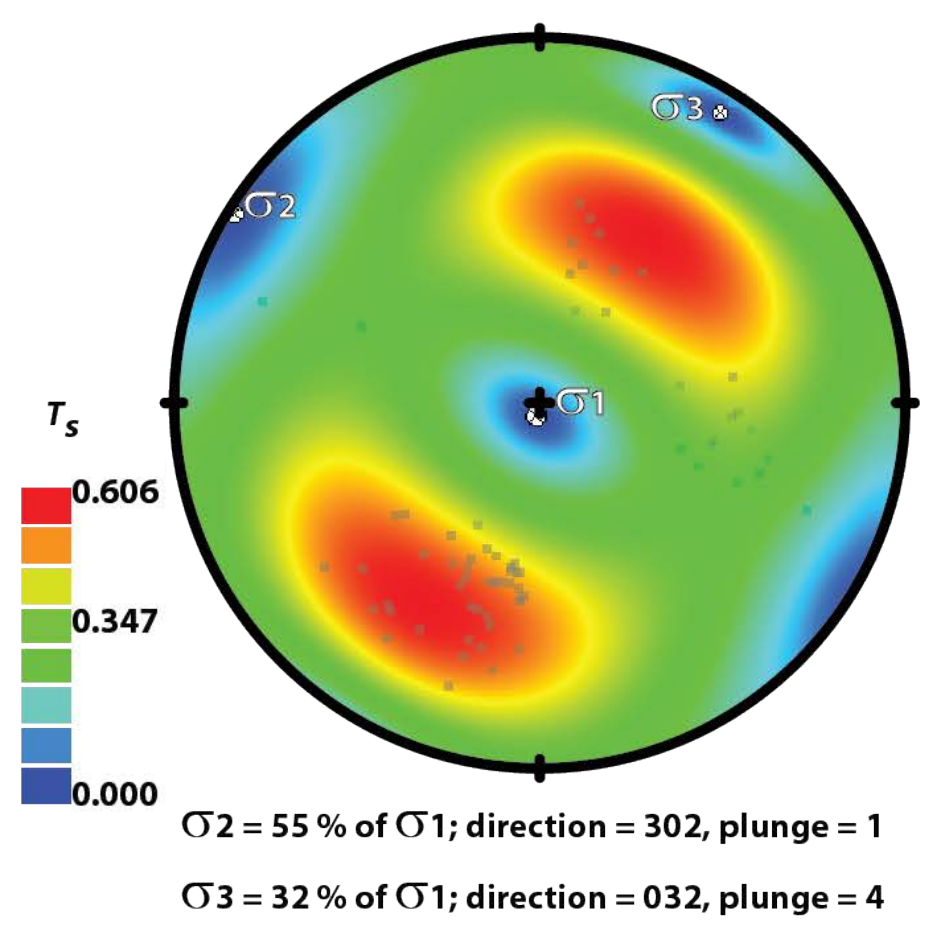




\begin{tabular}{|c|c|c|c|c|c|c|c|c|}
\hline & & & & $\sigma_{1}{ }^{\prime}$ & \multicolumn{2}{|c|}{$\sigma_{2}^{\prime}$} & \multicolumn{2}{|c|}{$\sigma_{3}{ }^{\prime}$} \\
\hline & $\sigma_{v}{ }^{\prime}, \%$ & $\sigma_{\mathrm{v}}{ }^{\prime}, \mathrm{MPa}$ & Overburden, km & $\mathrm{MPa}$ & $\%$ of $\sigma_{1}{ }^{\prime}$ & $\mathrm{MPa}$ & $\%$ of $\sigma_{1}{ }^{\prime}$ & $\mathrm{MPa}$ \\
\hline $\mathrm{FW}$, minimum & 98.63 & 19.00 & 1.20 & 19.26 & 54.00 & 10.40 & 32.00 & 6.16 \\
\hline FW, preferred & 98.63 & 23.80 & 1.50 & 24.13 & 54.00 & 13.03 & 32.00 & 7.72 \\
\hline FW, maximum & 98.63 & 43.00 & 2.70 & 43.60 & 54.00 & 23.54 & 32.00 & 13.95 \\
\hline $\mathrm{HW}$, minimum & 98.54 & 19.00 & 1.20 & 19.28 & 49.00 & 9.45 & 29.00 & 5.59 \\
\hline HW, preferred & 98.54 & 23.80 & 1.50 & 24.15 & 49.00 & 11.83 & 29.00 & 7.00 \\
\hline HW, maximum & 98.54 & 43.00 & 2.70 & 43.64 & 49.00 & 21.38 & 29.00 & 12.65 \\
\hline
\end{tabular}

